OECDpublishing

\title{
REVIEWING INDICA AND JAPONICA RICE MARKET DEVELOPMENTS
}

OECD FOOD, AGRICULTURE AND FISHERIES PAPER

April $2021 \quad \mathbf{n}^{\circ} \mathbf{1 5 4}$ 


\title{
OECD TRADE AND AGRICULTURE DIRECTORATE
}

\author{
REVIEWING INDICA AND JAPONICA RICE \\ MARKET DEVELOPMENTS
}

\author{
Tatsuji Koizumi and Stephan Hubertus Gay (OECD) \\ Gen Furuhashi (Policy Research Institute, MAFF, Japan)
}

\begin{abstract}
Indica and Japonica are the two major types of rice traded on the global market. Product characteristics, production zones, consumer preferences, and government policies influence Indica and Japonica rice market structures. Using the Rice Economy Climate Change (RECC) model, which covers these rice markets in 24 countries and the global rice market, the international Japonica rice price is found to be more volatile than that for Indica rice under possible climate change scenarios. The simulation results also suggest that agricultural investments in major countries producing Indica and Japonica rice will contribute to their price stability over the medium and long term under climate change.
\end{abstract}

Key words: Indica rice, Japonica rice, agricultural investments, climate change, price stability JEL Codes: C63, Q11, Q16, Q17

\section{Acknowledgements}

The authors are grateful to Annelies Deuss and Lee Ann Jackson (OECD), Jun Furuya, and Osamu Koyama (Japan Research Center for Agricultural Sciences), Shingo Kimura (Asian Development Bank), Byung Min Soon (Korea Rural Economic Institute), Nathan Childs (Economic Research Service, United States Department of Agriculture) for their review and valuable comments, and Michèle Patterson for preparing this report for publication. The authors also wish to thank the members of the OECD Joint Working Party on Agricultural Policies and Markets for their valuable comments and direction. 


\section{Table of contents}

Executive Summary 3

1. Introduction 4

2. Reviewing global rice market structures for Indica and Japonica 4

3. Global Indica and Japonica rice markets 11

4. Method and data for developing a partial equilibrium model 14

5. Results 18

6. Conclusions 21

References $\quad 23$

Annex A. Equations for rice production and consumption 26

Annex B. Parameters for major countries and region $\quad 28$

Annex C. Detailed tables for baseline and scenario projections 34

\section{Tables}

Table 1. Differences between Indica and Japonica varieties

Table 2. Global Japonica rice market $\quad 12$

Table 3. Global Indica rice market

Table 4. Growth rate of agricultural investments under baseline and scenario assumptions 18

Table A B.1. Estimation of parameters for Indica rice yields in major producing countries 28

Table A B.2. Estimation of parameters for Japonica rice yields 29

Table A B.3. Estimation of parameters for Indica rice planted areas in major producing countries 30

Table A B.4. Estimation of parameters for Japonica rice planted area 31

Table A B.5. Estimation of parameters for Indica rice per capita consumption 32

Table A B.6. Estimation of parameters for Japonica rice per capita consumption 33

Table A C.1. Global Indica rice market (baseline projection) (1) 34

Table A C.2. Global Indica rice market (baseline projection) (2) 35

Table A C.3. Global Japonica rice market (baseline projection) (1) 35

Table A C.4. Global Japonica rice market (the baseline projection) (2) 36

Table A C.5. Scenario impact on world Indica and Japonica rice markets (2015/17-2040) (1) 36

Table A C.6. Scenario impact on world Indica and Japonica rice markets (2015/17-2040) (2) 37

Table A C.7. Scenario impact on international Indica and Japonica rice prices (2015/17-2040) 37

\section{Figures}

Figure 1. Head rice percentage in main producing countries (2016) 6

Figure 2. Chinese Minimum Purchase Price (MPP) 9

Figure 3. Rice prices in the United States and Thailand 10

Figure 4. European rice prices 10

Figure 5. Structure of the RECC model for the Japonica rice market 17

Figure 6. Viet Nam scenarios: Impact on the Indica rice markets compared to baseline 19

Figure 7. The Philippines scenarios: Impact on the Indica rice markets compared to baseline 19

Figure 8. China scenarios: Impact on the Japonia and Indica rice markets 20

Figure 9. Coefficient of variation for Indica and Japonica prices 21 


\section{Executive Summary}

Indica and Japonica are the two major types of rice traded on the global market. Despite their different market structures in terms of production zones, consumer preferences and policies, most agricultural models do not distinguish between the two varieties.

This study projects future global Indica and Japonica rice markets over the medium and long term. To incorporate the impact of climate change, a new partial equilibrium model was developed: the Rice Economy Climate Change (RECC) model. This model covers Indica and Japonica rice markets in 24 countries and regions (Thailand, Viet Nam, Indonesia, Malaysia, the Philippines, Cambodia, Lao PDR, Myanmar, the People's Republic of China - hereafter "China", Japan, Korea, India, United States, EU28, Bangladesh, Sri Lanka, Nepal, Pakistan, Brazil, Côte d'Ivoire, Egypt, Madagascar, Nigeria, and the rest of the world), as well as the global rice market.

The results of the baseline projection and scenario simulations with the RECC model show that climate change is expected to impact Indica and Japonica production. More specifically, the international Japonica rice price is projected to be more volatile than the international Indica price, due to the smaller international market and higher protection policy measures. A small number of countries and regions are expected to account for most of the global exports of both types of rice. In contrast, global Indica and Japonica rice imports are projected to be more dispersed compared with exports in the baseline and all scenarios.

This study examines how agricultural investments would affect global Indica and Japonica markets in the case of climate change, especially the stability of international rice prices over the medium and long term. Agricultural investment scenarios were developed for three countries: Viet Nam, the Philippines, and China. The simulation results suggest that agricultural investments in major countries producing Indica and Japonica rice will contribute to their price stability over the medium and long term under climate change. More specifically, investments in agricultural knowledge and innovation systems in China and Viet Nam seem to contribute the most to stabilising international prices. 


\section{Introduction}

There are many varieties of rice produced and consumed, but the two major types of rice traded on the global market are Indica and Japonica rice. Various analytical approaches have been used to examine current and future markets for these two varieties. OECD-FAO (2018) illustrated Japonica rice production and trade shares in the global and domestic markets. OECD-FAO (2020) published global Japonica and Indica rice market data from 2003 to 2017. As regards models for rice projections, Wailes and Chavez (2011) developed the Arkansas Global Rice Model, distinguishing only the markets for long-grain and short- and medium-grain rice in the United States without specifying the markets for other types of rice. Koizumi and Furuhashi (2020) projected and simulated the future global Indica and Japonica rice markets under climate change by developing a partial equilibrium model. It simulated Representation Concentration Pathways (RCP) scenarios and projected the global Indica and Japonica rice markets under climate change without specifying the impact of agricultural investments. With a view to understanding the role of investment in shaping rice markets, this study uses a partial equilibrium model to examine how agricultural investments would contribute to stabilising global Indica and Japonica rice prices in the mid- and longterm.

\section{Reviewing global rice market structures for Indica and Japonica}

\section{Market structures for Indica and Japonica rice}

\section{Varieties}

There are two major species of cultivated rice: Oryza sativa and Oryza glaberrima. The rice varieties grown worldwide belong overwhelmingly to the Oryza sativa species. Nerica is a hybrid species that crosses the two varieties. Many Oryza Sativa varieties are cultivated commercially throughout the world. They belong to two major subspecies: Indica, mainly long-grain rice that grows in tropical, subtropical, and partly temperate zones; and Japonica, a round-grain rice grown in temperate zones. Basmatic and fragrant rice are categorised under Indica rice. The genetic variation in the Indica group is much larger than in the Japonica group.

Kato and Maruyama (1928) indicated that rice varieties could be divided into Indica and Japonica. These varieties differ considerably in their agronomical characteristics, such as length and length/width ratio. The length of long-grain rice (Indica) is between $6.6 \mathrm{~mm}$ and $7.5 \mathrm{~mm}$; that of medium rice (Japonica) is between 5.5 and $6.6 \mathrm{~mm}$; and short-grain rice (Japonica) is under $5.5 \mathrm{~mm}$. The length/width ratio of long-grain rice (Indica) is more than 3.0 ; that of medium rice (Japonica) is between 2.1 and 3.0 ; and short-grain rice (Japonica) is less than 2.1 (Mizuno, 2015). Many agronomic characteristics - such as tolerance to cold, drought resistance of seedlings, lodging resistance, nitrogen response of grain yield, nitrogen uptake by seedlings, competitive ability, minimum germination temperature, temperature response of seed germination and growth rate, and seed longevity in storage - also differ significantly between Indica and Japonica (Table 1). As such, Indica and Japonica rice reflect different genetic variations. 
Table 1. Differences between Indica and Japonica varieties

\begin{tabular}{|c|c|c|}
\hline Character & Indica & Japonica \\
\hline Cold tolerance & Low & High \\
\hline Drought resistance of seedlings & High & Low \\
\hline Lodging resistance & Low & High \\
\hline Nitrogen response of grain yield & Low & High \\
\hline Nitrogen uptake by seedlings & High & Low \\
\hline Competitive ability & High & Low \\
\hline Minimum germination temperature & High & Low \\
\hline Temperature responses of seed germination and growth rate & High & Low \\
\hline Seed longevity in storage & Long & Short \\
\hline
\end{tabular}

Source: Morishima and Oka (1981).

Oka (1953) stated that Japonica rice varieties could be divided into temperate and tropical ones. Indica, temperate Japonica, and tropical Japonica include glutinous ${ }^{1}$ and non-glutinous varieties. Temperate Japonica rice is mostly grown in temperate ecosystems with a relatively cool environment such as those in Japan, Korea, northern China, and California in the United States. Tropical Japonica is cultivated in the United States (Arkansas, Louisiana, and other states), and upland areas of Southeast and East Asia, and others. The temperate Japonica rice group has a closer genetic relationship with the tropical Japonica rice group than with the Indica group (Lee et al., 2018). Tropical Japonica rice is typically consumed in the domestic Indica rice markets because its appearance and taste are similar to Indica rice. Therefore, in this study, we include the temperate Japonica rice variety in the Japonica rice market, and tropical Japonica, Indica, and other rice in the Indica rice market. ${ }^{2}$

The milling process is more complicated for Indica than it is for Japonica rice, as Indica is longer and thinner. The broken rice ratio for long-grain rice (Indica) is 15-40\%; that for medium rice (Japonica) is 10$20 \%$; and that for short-grain rice (Japonica) is 1-3\% (Mizuno, 2015). In general, two types of milling machines (a grinding type for polishing rice and a friction type for removing rice bran) are used to mill Japonica rice. By contrast, three types of milling machines (a grinding type for polishing, a friction type for removing rice bran, and a polishing type) are used to mill Indica rice (Mizuno, 2015). As a result of these differences in processing and the high broken rice ratio, the head rice percentage ${ }^{3}$ of Indica is lower than that of Japonica rice; that of Indica is between $59 \%-68 \%$, and that of Japonica is between $69 \%-75 \%$ (Figure 1). Thus, both the milling process and the head rice percentage of Indica and Japonica differ.

\footnotetext{
${ }^{1}$ Glutinous rice is mostly grown in Southeast Asia and some parts of East Asia. It usually becomes stickier when cooked than do other types of rice.

2 This study does not focus on genetic strictness of rice types, but explores the conventional major rice types, Indica and Japonica rice, based on practical rice market separation.
}

${ }^{3}$ The head rice percentage is the volume or weight of head rice or whole kernel in the rice sample (IRRI 2019). 
Figure 1. Head rice percentage in main producing countries (2016)

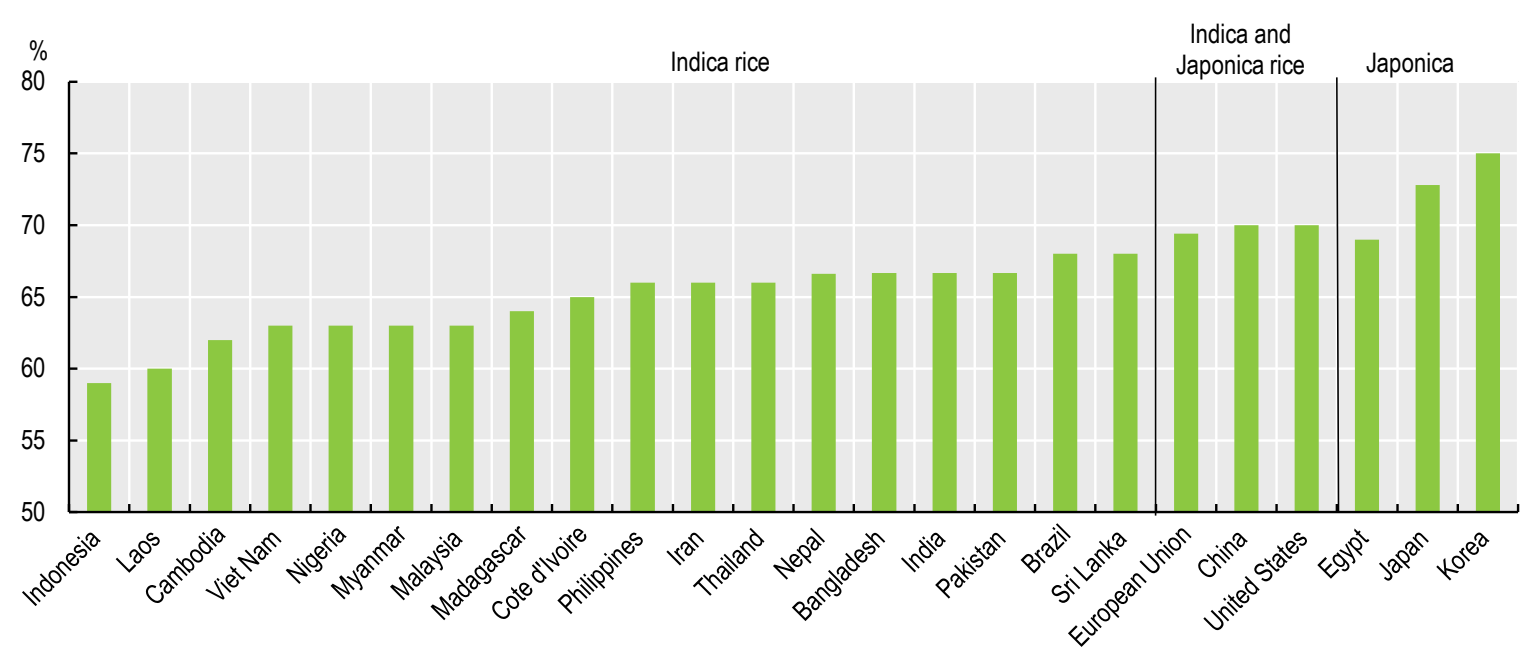

Source: AFSIS (2016) and USDA-FAS (2018b).

\section{Production zones}

Indica rice is produced in tropical, subtropical, and partly temperate zones, while Japonica rice is mainly produced in temperate zones with cooler climates. Indica rice varieties are produced mainly in India, Bangladesh, Thailand, Viet Nam, Indonesia, Myanmar, the Philippines, and China (in the provinces of Hunan, Hubei, Jiangxi, and other areas in southern China). Temperate Japonica rice varieties are produced mainly in other parts of China (Heilongjiang, Jilin, and Liaoning provinces, and in parts of Jiangsu, Anhui, and Hubei provinces, all mainly in northern China), California in the United States, Japan, Korea, the European Union, Egypt, and Turkey. Tropical Japonica varieties are produced mainly in Arkansas and Louisiana in the United States, certain parts of Iran, and some South American countries. Consequently, Indica and Japonica rice seldom compete for land use.

Both rice varieties are produced at the regional level in China. Jiangsu province produced mainly Indica rice until the 1980s. Through a government promoted agricultural program, planting shifted from Indica to Japonica rice as of 1990, due to higher margins on Japonica rice production compared to Indica and other crops (wheat, corn, and soybeans) (MAFF, 2014). In Jiangsu province, the production ratio of Japonica rice to total rice production increased from $50.6 \%$ in 1992 to $83.0 \%$ in 2007 and $89.1 \%$ in 2012 (MAFF, 2014). Areas planted could shift between Indica and Japonica rice in border areas that ran between temperate and subtropical zones. However, these areas became marginal in the next decade as the growth rate gradually slowed. In China, the assumption was that Indica rice production would decrease in the future, reflecting the global decrease in the minimum purchase price (MPP) of Indica below that of Japonica. Even though both rice types have been produced in China, The amount of rice production in Jiangsu province accounted for $0.5 \%$ of global Indica rice production. ${ }^{4}$ Consequently, the shift in production has not affected the global rice market structure for Indica rice, and the limited amount of rice reserved for export means that shifts in production have not affected the global rice market structure for Indica and Japonica rice.

Indica rice can be harvested up to three times a year in tropical zones, e.g. in Viet Nam and Indonesia. It can be harvested twice a year in Thailand, southern China, and other tropical Asian zones. Japonica rice is usually harvested once a year as it is mostly produced in temperate zones.

\footnotetext{
4 The rice data for Jiangsu province in 2012 was derived from MAFF (2014), and the global Indica rice production data in 2012 was obtained from Koizumi and Furuhashi (2020).
} 


\section{Consumer preferences}

The amylose and amylopectin content are crucial factors that determine the taste and texture differences in rice varieties. The amylose content of Indica is usually higher than that of Japonica rice; Indica's amylose content share to total weight is generally $26-31 \%$ and that of Japonica is $17.3-19.7 \%$ (Ishitani, 1993). As such, Japonica has a more glutinous texture than Indica rice.

Cooking styles may also affect the taste of rice based on its amylose content; Indica rice is boiled, while Japonica rice can be boiled and steamed. However, in many cases, boiled Indica rice is then cooked and fried with main or side dishes (meats, fish, and vegetables) or soused with curry, gambo, and other types of soup. The high amylopectin content of Japonica rice contributes to a higher thickness and sweetness in taste. In general, and contrary to Indica rice, Japonica rice maintains its texture after cooking, depending on the keep-warm function of the rice cooker used. This makes Japonica rice popular in cooking applications such as sushi and rice balls. Consequently, cooking styles reinforce the differences in taste between Indica and Japonica rice.

In the northern provinces of China, Japan, Korea, Chinese Taipei, Egypt, and Australia, consumers typically prefer low amylose rice. By contrast, rice with an intermediate amylose content is preferred in Iran, Pakistan, Malaysia, the Philippines, Viet Nam, Indonesia, and Uruguay. High amylose varieties are popular in Myanmar, Sri Lanka, many Indian states, Ghana, Senegal, and Colombia (Calingacion et al. 2014).

Aromatic rice, primarily basmati and jasmine rice, is not normally categorised under Indica rice. Aromatic rice varieties are valuable in the Indica rice market and typically sell at a premium price. Aromatic rice is preferred in Thailand, Viet Nam, Lao PDR, Cambodia, Malaysia, Myanmar, Iran, Pakistan, and India. In contrast, aromatic rice is less appreciated in Japan, Korea, and some East Asian countries (Calingacion et al. 2014).

Powdered rice is a unique and popular ingredient in countries that prefer Indica rice. For instance, rice noodles in the southern part of China and pho in Viet Nam are popular foods made from powdered rice. As the broken rice ratio in Indica is higher than in Japonica, a special market for broken rice exists in Southeast Asian countries. The relatively higher broken rice ratio can contribute to the powdered rice market development that supports the cooking styles in these countries. However, powdered rice is not popular in countries and regions where Japonica rice is preferred, except for Chinese Taipei, due to food culture and traditions.

Due to strong consumer preference for one rice over the other, it is difficult to assume that Japonica rice consumption will precipitously increase in countries and regions that prefer Indica rice, even if per capita income increases or Japonica price becomes relatively lower in price. ${ }^{5}$ For example, even when Japan depended on imported rice from Thailand because of a poor harvest in $1993,{ }^{6}$ Japanese consumers continued to prefer Japonica to Indica rice despite the severe shortage of domestic Japonica rice and the extreme price difference. In Korea, rice imports are sensitive to consumer preferences for different rice types (Soon et al., 2019). No assumption can therefore be made that preferences and tastes for rice will change dramatically with income and price effects.

Koizumi and Furuhashi (2020) estimated rice price elasticity for per capita consumption of Indica and Japonica rice in China, the United States, Japan, Korea, the European Union, and Egypt. ${ }^{7}$ The results indicated that Indica and Japonica rice had minimal substitution effect in China; however, they did not

\footnotetext{
${ }^{5}$ Japonica rice price is normally higher than Indica rice price in countries and regions.

${ }^{6}$ Japanese rice imports increased from 21000 tonnes in 1992 to 2186000 tonnes in 1994 (MAFF, 2018).

7 Results are shown in annex Tables A.B.5 and A.B.6.
} 
confirm there was rice substitution in other countries and regions. Accordingly, little substitution is assumed between Indica and Japonica rice consumption at the global level based on strong consumer preferences under normal market conditions. ${ }^{8}$ Strong consumer preferences for one or the other type of rice is the most crucial factor in determining differences in these markets.

\section{Rice policies}

As rice is a staple food in many countries, it is viewed as a political and strategic commodity. Stabilising domestic rice prices is a crucial policy target for most rice producing and consuming countries. Rice trading on global markets represented only $9.2 \%$ of the world's production in 2016-2018, compared with $23.7 \%$ for wheat, $14.2 \%$ for maize, and $42.7 \%$ for soybeans. ${ }^{9}$ This narrow international rice market is the result of, and the reason for, highly protective policies. Rice policies have been traditionally oriented towards selfsufficiency rather than self-reliance strategies (Calpe, 2006).

As such, governments have implemented wide-ranging controls and interventions for rice prices, production, trade, distribution, and stocks. For example, rice exports are managed by state-trading enterprises (STEs) and other government institutions in China, India, Viet Nam, and Myanmar. These STEs can also import rice. Many countries have set tariffs on rice at a very high level, often more than $50 \%$, or have designated that rice is eligible for special safeguards (Calpe, 2006). Moreover, some countries (India, Viet Nam, the Philippines, and Egypt) have implemented an export ban or restrictions in order to stabilise domestic prices.

The government of China implemented a Minimum Purchase Price (MPP) in 2004, and which is applied to early, medium, and late Indica, Japonica, and wheat (white, red, and mixed wheat) harvests. The MPP for Japonica rice was set at a higher rate than that for early, medium, and late Indica rice, and wheat (Figure 2). As a result of increasing income in the city areas of the northern Chinese provinces, per capita Japonica rice demand increased from $20 \mathrm{~kg}$ in 1990 to $30 \mathrm{~kg}$ in 2010 (MAFF, 2014), as the main staple grain consumption shifted from wheat to Japonica rice. Consequently, the government established incentives for farmers to increase Japonica rice production as demand increased and its production margins remained higher than that of other crops. As a result, the Japonica rice planted area ratio to total rice planted area in China increased from 11\% in 1980 to $29 \%$ in 2012 (MAFF, 2014).

Historically, Indica rice has enjoyed relatively lower tariffs, while trade in Japonica rice has been restricted due to the high level of protection policies (Calpe, 2006). The Japanese rice market was closed until 1995 (except for emergency rice imports in 1993 due to harvest shortfall) when the General Agreement on Tariffs and Trade (GATT) Uruguay Round of negotiations led to the opening of the market. Consequently, Japan accepted minimum access (MA) quotas on rice imports starting at 379000 tonnes in 1995, increasing to 682000 tonnes by 2020 (USDA-FAS). ${ }^{10}$ Furthermore, Japan started tariffication of rice as of 1999.

\footnotetext{
8 Japonica rice can substitute for Indica rice when the price of the latter is higher than for Japonica price in a model. However, this market condition rarely occurs, and thus does not affect the global market structures in the long term.

9 These production and export data are derived from OECD-FAO (2019).

10 These amounts were milled rice equivalent and applied to the Japanese fiscal year (April to March).
} 
Figure 2. Chinese Minimum Purchase Price (MPP)

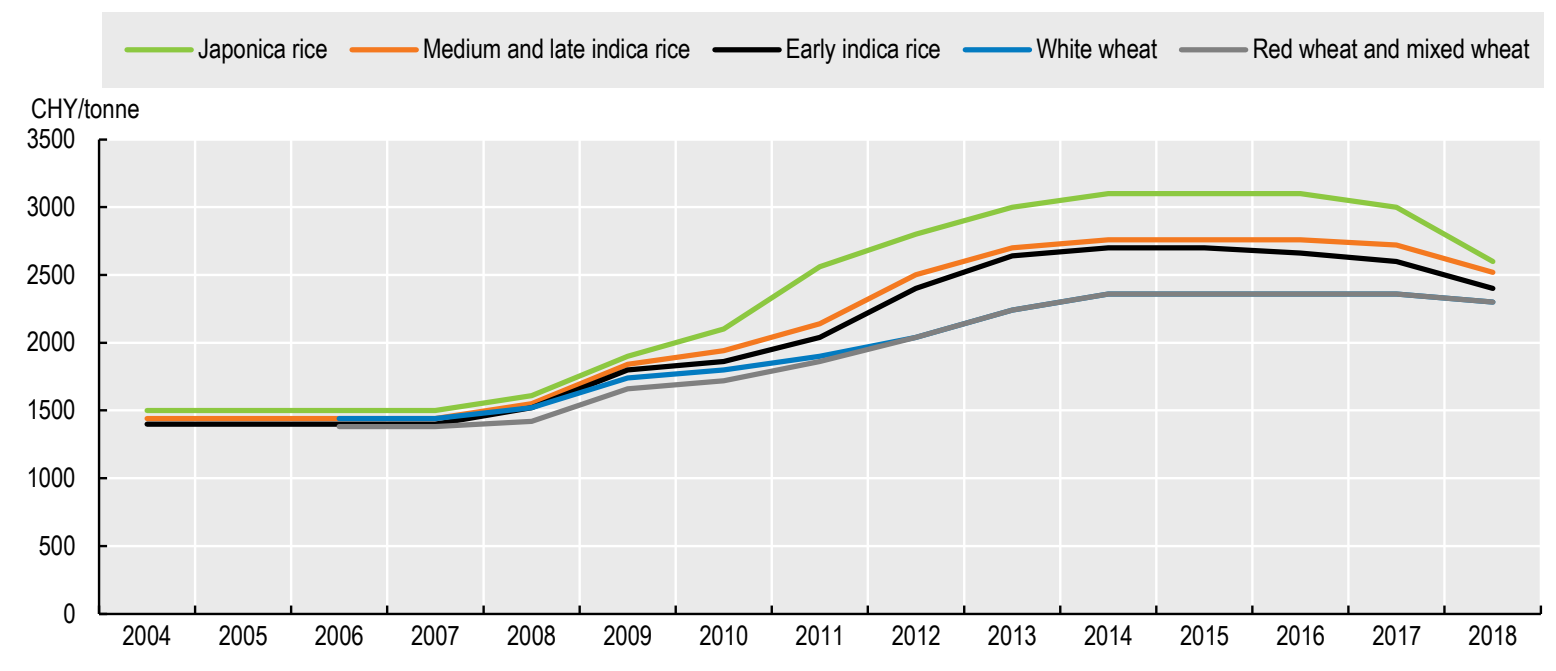

Source: National Development and reform Commission (2019).

Following the Uruguay Round, Korea increased its minimum access tariff rate quota (TRQ) from 51000 tonnes in 1995 to 409000 tonnes in 2015, with the United States the largest rice exporter to Korea, accounting for 39.5\% of total imports in 2017 (Global Trade Atlas, 2019). The government of Chinese Taipei set a TRQ for rice imports as of 2003, with the United States its largest rice supplier, accounting for 44.1\% of total imports in 2017 (Global Trade Atlas, 2019). Thus, Japan, Korea, and Chinese Taipei are importing Japonica rice, mainly from the United States.

In 2011, California rice production was 1550000 tonnes (USDA-ERS, 2012) with domestic consumption at 850000 tonnes and exports at 700000 tonnes. Of those exports, 360000 tonnes were exported to Japan, 80000 tonnes to Korea, and 50000 tonnes to Chinese Taipei (Ito, 2015). Japan was the largest Japonica rice importer from California, which helps to explain why this state's rice prices remained high while Indica rice prices in the southern United States followed the Thai reference prices. The strong Japanese demand for California rice helped maintain its high rice prices (Ito, 2010).

\section{Indica and Japonica prices and markets}

The international reference price of rice is normally Thailand's export price of $5 \%$ broken milled white rice, which acts as an indicator for the price of long-grain Indica rice. The export price of California's f.o.b. average monthly milled rice acts as an indicator for the price of Japonica rice at the international level (OECD-FAO, 2018). Most Japonica rice markets rely on domestic production and specific trade policies that limit imports, with the result that domestic prices are higher than the international rice price. As such, potential uncertainties in the commodity markets could trigger volatility in the short term in consumption, production, and prices in the smaller global Japonica rice market compared to the market for Indica and other major grains (OECD-FAO, 2018). In the current context, the Japonica rice price is higher than the Indica rice price internationally, and in the United States and the European Union (Figures 3 and 4). 
Figure 3. Rice prices in the United States and Thailand

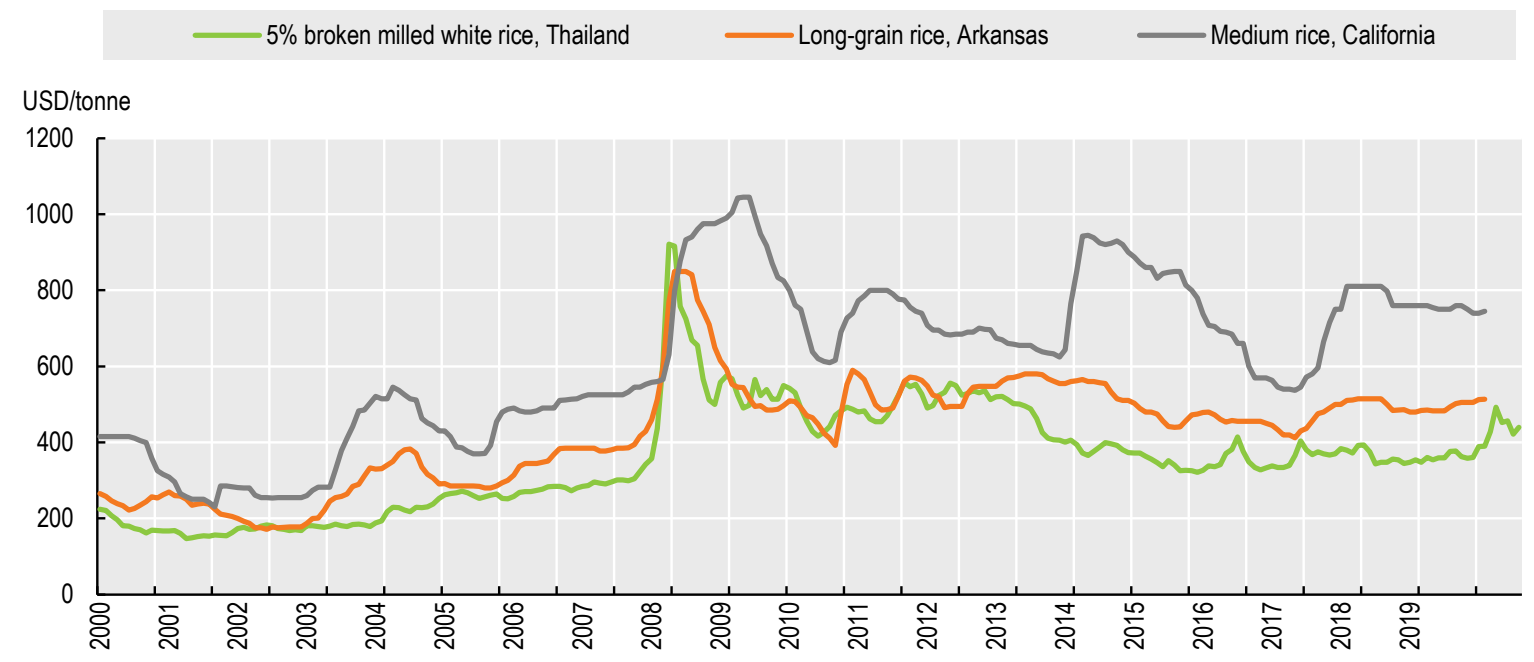

Note: The medium rice price in California is considered the reference price for Japonica rice produced in the United States. Source: USDA-ERS (2020) and IMF (2020).

\section{Figure 4. European rice prices}

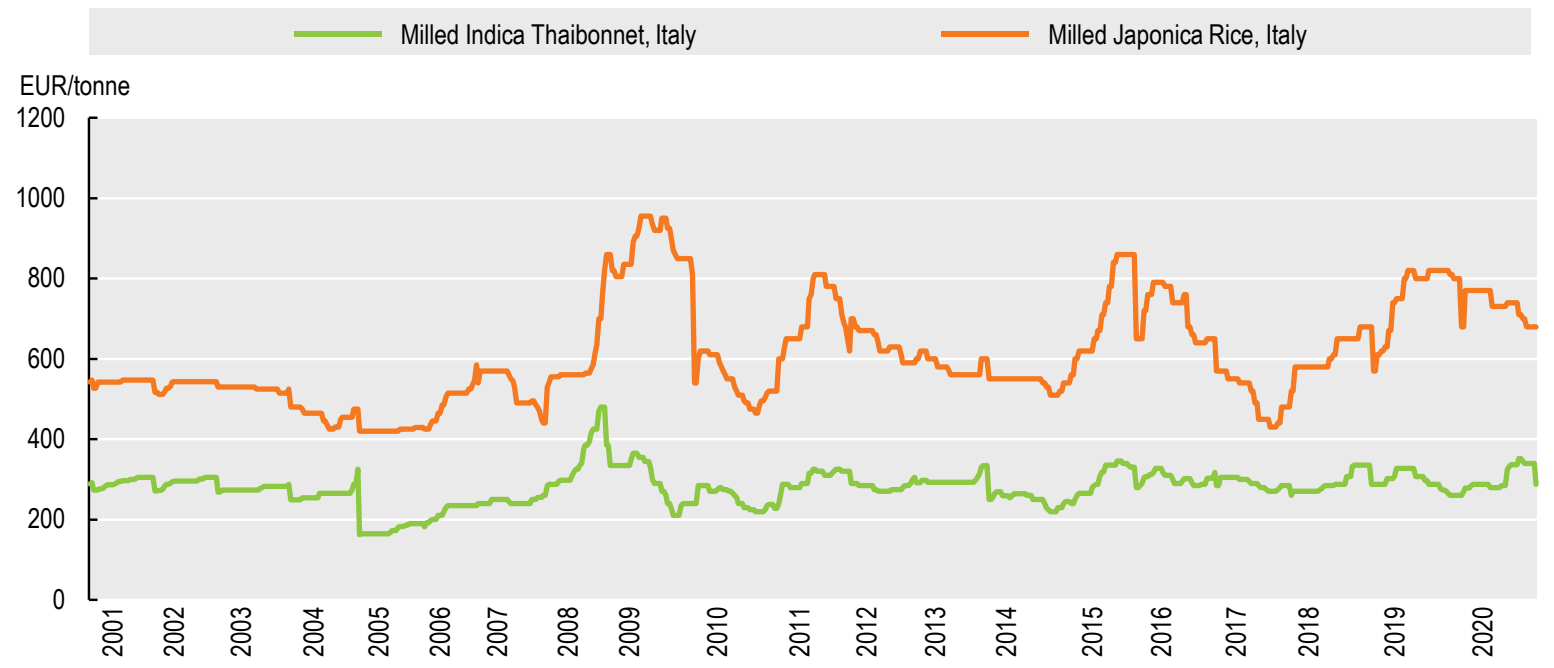

Source: European Commission (2020).

The lower ratio of broken rice, and the shiny and aromatic rice characteristics command a higher price in the Indica rice market. By contrast, the lower content of amylose and the higher content of amylopectin are the main factors that determine the grade of rice and command the higher price in the Japonica rice market. Consequently, the main factors influencing rice grade and price are different in each market, depending on the income, population, and production.

Several studies assessed separated rice markets. Petzel and Monke (1980) did not find any evidence for the linkage of US and Thailand rice prices. Falcon and Monke (1980), Siamwalla and Haykin (1983) and Rastegari-Hennberry (1985) asserted that rice markets are divided into Indica and Japonica. Ito (2015) argued that Indica and Japonica rice markets were separated. Dawe (2010) concluded there was little 
correlation between movements in the US rice prices and Asian export prices, and that the US markets did not influence Asian markets. John (2014) also conducted a time-series analysis showing that Asian and US rice prices were not related.

This study uses an Error Correction Model (ECM) to evaluate the long-term equilibrium relationships of economic variables. Section 4 and Annex B elaborate on data and parameters for Indica and Japonica rice yield, areas harvested, and per capita consumption. Results of the regressions show that Indica and Japonica rice do not compete for land use or consumption in 24 important countries. However, the consumption of indica rice seems to substitute for Japonica rice in China. The significance of this result is nevertheless statistically low and, in view of this, studies focus on consumption impacts. The results could be usefully complemented by further analysis that examine the production aspects of rice markets.

\section{Global Indica and Japonica rice markets}

This study assumes that the Japonica rice market is composed exclusively of temperate Japonica rice, while the Indica rice market is composed of all the other varieties (including tropical Japonica rice). As such, this study first estimates Japonica rice production, consumption and trade; it then obtains Indica rice production, consumption and trade by subtracting the Japonica data from the total rice data. The constructed separation of world rice markets is based on many assumptions that are not reflected in official data or statistics.

Japonica rice production and harvested area shares of total rice in China are estimated using the country's statistical yearbook (National Bureau of Statistics of China, 2017), and through discussions with researchers of the Chinese Academy of Agricultural Sciences (CAAS). Trade estimates of Japonica rice in China are based on China's rice custom data in the UN Comtrade database (United Nations Statistics Division, 2018) with countries producing and consuming mainly Japonica rice, such as Australia, Japan, and Korea. China's Japonica rice balance is estimated from USDA PS\&D statistics (USDA-FAS, 2018b) balance sheet for Chinese rice. Furthermore, Japonica rice stocks in China are calculated by its estimated production shares multiplied by China's rice stock statistics of the USDA PS\&D (USDA-FAS, 2018b) because the Chinese government has not released any production detail for many years. Japonica rice stock in the United States and the European Union is estimated based on statistics from the USDA National Agricultural Statistics Service (USDA-NASS, 2018) and EUROSTAT (European Commission, 2018b) respectively. Japonica rice stocks in other countries are calculated by their estimated production shares multiplied by rice stock statistics as reported in USDA PS\&D (USDA-FAS, 2018b). The balances of Japonica rice in the other countries listed in Table 2 are estimated from trade shares of Indica and Japonica rice, custom statistics of the countries covered based on the UN Comtrade Database (United Nations Statistics Division, 2018), and the country rice balance sheets of the USDA PS\&D (USDA-FAS, 2018b). 
Table 2. Global Japonica rice market

\begin{tabular}{|c|c|c|c|c|c|c|c|}
\hline$(1000 t)$ & 2003 & 2017 & $\begin{array}{c}\text { Annual growth rate } \\
(2003-2017)\end{array}$ & $(1000 t)$ & 2003 & 2017 & $\begin{array}{c}\text { Annual growth rate } \\
(2003-2017)\end{array}$ \\
\hline \multicolumn{4}{|l|}{ Production } & \multicolumn{4}{|l|}{ Exports } \\
\hline World & 47329 & 71255 & $3.0 \%$ & World & 2067 & 2329 & $0.9 \%$ \\
\hline China & 29690 & 51116 & $4.0 \%$ & United States & 506 & 674 & $2.1 \%$ \\
\hline Japan & 7091 & 7586 & $0.5 \%$ & China & 72 & 765 & $18.3 \%$ \\
\hline Korea & 4451 & 3972 & $-0.8 \%$ & EU28 & no data & 263 & - \\
\hline United States & 1239 & 1167 & $-0.4 \%$ & Korea & 211 & 63 & $-8.3 \%$ \\
\hline EU28 & no data & 1497 & - & Japan & 230 & 50 & $-10.3 \%$ \\
\hline Egypt & 3900 & 4300 & $0.7 \%$ & Egypt & 826 & 50 & $-18.2 \%$ \\
\hline Thailand & 0 & 0 & - & Thailand & 0 & 0 & - \\
\hline Malaysia & 0 & 0 & - & Malaysia & 0 & 0 & - \\
\hline \multicolumn{4}{|l|}{ Consumption } & \multicolumn{4}{|l|}{ Imports } \\
\hline World & 53661 & 69286 & $1.8 \%$ & World & 2067 & 2329 & $0.9 \%$ \\
\hline China & 34626 & 47267 & $2.2 \%$ & Japan & 547 & 494 & $-0.7 \%$ \\
\hline Japan & 8148 & 8259 & $0.1 \%$ & Korea & 193 & 290 & $2.9 \%$ \\
\hline Korea & 4512 & 4755 & $0.4 \%$ & EU28 & no data & 156 & - \\
\hline Egypt & 3225 & 4351 & $2.2 \%$ & United States & 5 & 19 & $10.1 \%$ \\
\hline EU28 & no data & 1473 & - & Malaysia & 0 & 6 & - \\
\hline United States & 749 & 643 & $-1.1 \%$ & China & 1 & 1 & $1.9 \%$ \\
\hline Thailand & 0 & 0 & - & Egypt & 0 & 1 & - \\
\hline Malaysia & 0 & 6 & - & Thailand & 0 & 0 & - \\
\hline
\end{tabular}

Notes:

1. The rice balance of Japonica rice in selected countries mainly producing and exporting Japonica rice is principally estimated from trade shares of Indica and Japonica rice, custom statistics of the coverage countries, based on the UN Comtrade Database (United Nations Statistics Division, 2018) and the rice balance sheets of the USDA PS\&D (USDA-FAS, 2018b).

2. Some specific countries' balances with their trade, supply and demand are estimated using the statistics from National Bureau of Statistics of China (2017), China's National Statistical Bureau and the China National Grain and Oils Information Center (2018), Global Agricultural Trade System, Standard Query (USDA-FAS, 2018a), Data \& Statistics, Statistics by State, California Field Office (USDA-NASS (2018)), Rice Yearbook (USDA-ERS, 2018), Cereals, oilseeds, protein crops and rice (European Commission, 2018a), and Eurostat (European Commission, 2018b), including custom data of specific countries.

Table 2 shows the Japonica rice balances for the main producers, consumers, and traders of temperate Japonica rice. Global Japonica rice production was estimated at 71.3 million tonnes in 2017 and increased by an average of $3.0 \%$ per annum during 2003-2017. China accounted for $72 \%$ of the global Japonica rice production in 2017. Japan, Egypt, Korea and the United States are the other main producers. World Japonica rice consumption was estimated at 69.3 million tonnes in 2017, and exports and imports were estimated at 2.3 million tonnes. Japonica rice trade increased by $0.9 \%$ per annum during 2003-2017. Thus, in 2017 Japonica rice accounted for an estimated $14.6 \%$ of global rice production, $14.4 \%$ of global rice consumption, and $4.8 \%$ of global rice trade.

The global Indica rice production was estimated at 417.3 million tonnes in 2017, six times that of Japonica, and increased by $1.4 \%$ per annum between 2003 and 2017 (Table 3). India and China accounted for 49\% of the global Indica production in 2017. World Indica rice consumption was estimated at 412.1 million tonnes, and world Indica rice exports and imports at 45.9 million tonnes in 2017. Indica rice exports and imports increased by $4.3 \%$ and $5.1 \%$ per annum during the $2003-2017$ period. 
Table 3. Global Indica rice market

\begin{tabular}{|c|c|c|c|c|c|c|c|}
\hline$(1000 t)$ & 2003 & 2017 & $\begin{array}{c}\text { Annual } \\
\text { growth rate } \\
(2003-2017) \\
\end{array}$ & $(1000 t)$ & 2003 & 2017 & $\begin{array}{c}\text { Annual } \\
\text { growth rate } \\
(2003-2017)\end{array}$ \\
\hline \multicolumn{2}{|c|}{ Indica rice production } & & & \multicolumn{2}{|l|}{ Indica rice exports } & & \\
\hline World & 345168 & 417349 & $1.4 \%$ & World & 25397 & 45994 & $4.3 \%$ \\
\hline $\begin{array}{l}\text { Thailand } \\
\end{array}$ & 18011 & 20370 & $0.9 \%$ & \begin{tabular}{l|l} 
Thailand \\
\end{tabular} & 10137 & 10500 & $0.3 \%$ \\
\hline Viet Nam & 22082 & 28943 & $2.0 \%$ & Viet Nam & 4295 & 7000 & $3.6 \%$ \\
\hline Indonesia & 35024 & 37000 & $0.4 \%$ & Indonesia & 0 & 2 & - \\
\hline Malaysia & 1470 & 1820 & $1.5 \%$ & Malaysia & 13 & 50 & $10.1 \%$ \\
\hline India & 88522 & 110000 & $1.6 \%$ & India & 3100 & 12800 & $10.7 \%$ \\
\hline China & 82772 & 94873 & $1.0 \%$ & China & 808 & 535 & $-2.9 \%$ \\
\hline Japan & 0 & 0 & - & Japan & 0 & 0 & - \\
\hline Korea & 0 & 0 & - & Korea & 0 & 0 & - \\
\hline United States & 5181 & 4492 & $-1.0 \%$ & United States & 2804 & 2184 & $-1.8 \%$ \\
\hline EU28 & No data & 540 & - & EU28 & No data & 38 & - \\
\hline Cambodia & 2968 & 5399 & $4.4 \%$ & Cambodia & 300 & 1250 & $10.7 \%$ \\
\hline Lao PDR & 1230 & 2000 & $3.5 \%$ & Lao PDR & 0 & 75 & - \\
\hline Myanmar & 10730 & 13200 & $1.5 \%$ & Myanmar & 130 & 3300 & $26.0 \%$ \\
\hline Philippines & 9200 & 12300 & $2.1 \%$ & Philippines & 0 & 0 & - \\
\hline Bangladesh & 26152 & 32650 & $1.6 \%$ & Bangladesh & 0 & 4 & - \\
\hline Brazil & 8709 & 8075 & $-0.5 \%$ & Brazil & 79 & 850 & $18.5 \%$ \\
\hline Cote d'Ivoire & 280 & 1377 & $12.1 \%$ & Cote d'Ivoire & 1 & 30 & $27.5 \%$ \\
\hline Egypt & 0 & 0 & & Egypt & 0 & 0 & - \\
\hline Madagascar & 1792 & 1984 & $0.7 \%$ & Madagascar & 0 & 0 & - \\
\hline Nepal & 2970 & 3310 & $0.8 \%$ & Nepal & 0 & 0 & - \\
\hline Nigeria & 1870 & 3780 & $5.2 \%$ & Nigeria & 0 & 0 & - \\
\hline Pakistan & 4848 & 7500 & $3.2 \%$ & Pakistan & 1868 & 4300 & $6.1 \%$ \\
\hline Sri Lanka & 1900 & 2511 & $2.0 \%$ & Sri Lanka & 0 & 5 & - \\
\hline \multicolumn{2}{|c|}{ Indica rice consumption } & & & \multicolumn{2}{|l|}{ Indica rice imports } & & \\
\hline World & 357714 & 412077 & $1.0 \%$ & World & 22,946 & 45,846 & $5.1 \%$ \\
\hline Thailand & 9470 & 11170 & $1.2 \%$ & Thailand & 0 & 250 & - \\
\hline Viet Nam & 18230 & 22100 & $1.4 \%$ & Viet Nam & 300 & 400 & $2.1 \%$ \\
\hline Indonesia & 36000 & 38000 & $0.4 \%$ & Indonesia & 650 & 2000 & $8.4 \%$ \\
\hline Malaysia & 2030 & 2744 & $2.2 \%$ & Malaysia & 500 & 894 & $4.2 \%$ \\
\hline India & 85622 & 97350 & $0.9 \%$ & India & 0 & 0 & - \\
\hline China & 97474 & 95433 & $-0.2 \%$ & China & 1121 & 5499 & $12.0 \%$ \\
\hline Japan & 153 & 191 & $1.6 \%$ & Japan & 153 & 191 & $1.6 \%$ \\
\hline Korea & 0 & 120 & - & Korea & 0 & 120 & - \\
\hline United States & 2907 & 3452 & $1.2 \%$ & United States & 473 & 838 & $4.2 \%$ \\
\hline EU28 & No data & 2177 & - & EU28 & No data & 1744 & - \\
\hline Cambodia & 2733 & 4100 & $2.9 \%$ & Cambodia & 65 & 20 & $-8.1 \%$ \\
\hline Lao PDR & 1230 & 2100 & $3.9 \%$ & Lao PDR & 11 & 100 & $17.1 \%$ \\
\hline Myanmar & 10200 & 9900 & $-0.2 \%$ & Myanmar & 0 & 10 & - \\
\hline Philippines & 10250 & 13100 & $1.8 \%$ & Philippines & 1290 & 1200 & $-0.5 \%$ \\
\hline Bangladesh & 26700 & 35200 & $2.0 \%$ & Bangladesh & 850 & 3200 & $9.9 \%$ \\
\hline Brazil & 8700 & 8025 & $-0.6 \%$ & Brazil & 881 & 700 & $-1.6 \%$ \\
\hline Cote d'Ivoire & 1129 & 2900 & $7.0 \%$ & Cote d'Ivoire & 743 & 1500 & $5.1 \%$ \\
\hline Egypt & 0 & 49 & - & Egypt & 0 & 49 & - \\
\hline Madagascar & 1943 & 2659 & $2.3 \%$ & Madagascar & 151 & 675 & $11.3 \%$ \\
\hline Nepal & 2974 & 3910 & $2.0 \%$ & Nepal & 4 & 600 & $43.0 \%$ \\
\hline
\end{tabular}




\begin{tabular}{|c|c|c|c|c|c|c|c|}
\hline$(1000 t)$ & 2003 & 2017 & $\begin{array}{c}\text { Annual } \\
\text { growth rate } \\
(2003-2017)\end{array}$ & $(1000 t)$ & 2003 & 2017 & $\begin{array}{c}\text { Annual } \\
\text { growth rate } \\
(2003-2017)\end{array}$ \\
\hline Nigeria & 3670 & 6700 & $4.4 \%$ & Nigeria & 1448 & 2600 & $4.3 \%$ \\
\hline Pakistan & 2595 & 3200 & $1.5 \%$ & Pakistan & 0 & 0 & - \\
\hline Sri Lanka & 2075 & 3025 & $2.7 \%$ & Sri Lanka & 29 & 600 & $24.2 \%$ \\
\hline
\end{tabular}

Note: Indica rice production, consumption and trade balances are calculated as "Indica rice (production, consumption, and trades) = total rice Japonica rice", after the Japonica rice balances are estimated.

\section{Method and data for developing a partial equilibrium model}

\section{Method}

Instead of incorporating the separation of rice varieties into Aglink-Cosimo, a new model was developed to better reflect the specificities of global rice markets. The Rice Economy Climate Change (RECC) model covers rice markets in 24 countries and regions (Thailand, Viet Nam, Indonesia, Malaysia, the Philippines, Cambodia, Lao PDR, Myanmar, China, Japan, Korea, India, United States, EU28, Bangladesh, Sri Lanka, Nepal, Pakistan, Brazil, Côte d'Ivoire, Egypt, Madagascar, Nigeria, and the rest of the world) to represent the entire global rice market. ${ }^{11}$ The RECC model includes equations for projecting rice yield and harvested areas affected by climate change and agricultural investments (Figure 5). An Error Correction Model (ECM) evaluates the long-term equilibrium relationships among economic variables. Each country and region's market consists of production, consumption, exports, imports, and ending stocks for Indica and Japonica rice up to the year 2040, with the base year 2015-17 (three-year average for 2015, 2016 and 2017). A more detailed description of the model structures is included in Koizumi and Furuhashi (2020). Additional modification include parameters for Indica and Japonica rice yield and the areas harvested of the target countries and agricultural investment variables (agricultural knowledge, infrastructure, land development, and agricultural machinery \& equipment) from nominal base to real bases. Annex $A$ includes the equations of yield and planted area, and Annex B tables estimate parameters, which are applied to the projection in the present study.

\section{Data, baseline assumptions and scenarios}

Historical data for the planted area, yield, production, per capita consumption, imports, exports, and ending stocks for Indica and Japonica rice are estimated from PS\&D (USDA-FAS, 2018b). ${ }^{12}$ Historical annual data on minimum and maximum temperatures and precipitation are obtained from CRU TS. 3.2 (Climate Research Unit (CRU) of the University of East Anglia). For larger countries, the values for grids that correspond to major rice-producing areas are averaged (Koizumi and Furuhashi, 2020). For other countries, the values for all grids that cover the entire territory are spatially averaged.

The baseline scenario (hereafter the "baseline") adopts a set of assumptions for the general economy, agricultural policies, and technological changes without any shocks due to policy changes during the projection period. Population data for all countries were taken from the 2017 revision (medium variant) of the UN's World Population Prospects (United Nations, 2017). Per capita real GDP was treated as an exogenous variable, and GDP growth rate assumptions were set based on the OECD Economic Outlook

\footnotetext{
${ }^{11}$ We included the world's top 22 rice producers, and top 10 consumers, exporters and importers into the RECC model.

12 Historical rice data for Italy and Spain are derived from FAOSTAT (FAO, 2018). The results of unit root tests (ADF test) confirmed that the time-series data of dependent variables and explanatory variables used in this study are stationary series with logarithmic differences.
} 
No.144 (OECD, 2018) and the World Economic Outlook 2018 (IMF, 2018). ${ }^{13}$ The international wheat price was obtained from the OECD-FAO Agricultural Outlook 2019-2028, and are expected to increase from USD 212.5/t in 2015/17 to USD 237.5/t in 2028 (OECD-FAO, 2019). Current agricultural and trade policies are assumed to continue for the projection period in this study, and the abandoned area of cultivation is set to zero in all countries throughout the study period.

The climate variables (minimum and maximum temperatures, and precipitation) in each country and region are exogenous to the model, and all climate variables for both the baseline and Representation Concentration Pathways (RCP) scenarios in this study are derived from future climate change projections made by the Model for Interdisciplinary Research on Climate (MIROC), a global climate model under the RCP 4.5 scenario. ${ }^{14}$ The RCP 4.5 scenario denotes an intermediate emission scenario among all RCP scenarios. Therefore, this study applies the RCP 4.5 scenario's climate conditions to the climate change assumption for the baseline. ${ }^{15}$ Spatially averaged climate variables for each country are computed in the same manner as the historical climate data used for regression estimation. The standard deviations of the minimum and maximum temperatures and precipitation are projected to increase from the decades 19802009 to 2015-2040 in most target areas and countries based on the above climate conditions (Koizumi and Furuhashi, 2020).

This study applies agricultural investment data as agricultural knowledge and infrastructure derived from the OECD's General Service Support Estimates (GSSE) to China, Japan, Korea, United States, EU28, Viet Nam, and the Philippines (OECD, 2019). ${ }^{16}$ Land development and agricultural machinery and equipment estimates are applied to the other developing countries. ${ }^{17}$ We assume that the current growth rates of investments in agricultural knowledge and innovation systems and development and maintenance of infrastructure from 2010 to 2017 continue for the projection period (2015/17-2040) (Table 4). ${ }^{18}$ We also assume that the growth rates of investments in agricultural machinery \& equipment and land development from 2000 to 2007 in the other developing counties, based on available information on FAOSTAT, will continue for the projection period. These are all in real terms and deflated with each country and region's CPI. The annual CPI data are obtained from the IMF's International Financial Statistics (IMF, 2019).

\footnotetext{
13 These GDP growth rates are available until the year 2023. This study assumes the average per capita GDP growth rates from 2017 to 2023 in each country will continue to be the same during 2024-2040.

${ }^{14}$ RCPs are time and space dependent trajectories of concentrations of greenhouse gases and pollutants resulting from human activities, including changes in land use. RCP 4.5 is defined as stabilisation without an overshoot pathway to $4.5 \mathrm{~W} / \mathrm{m} 2$ at stabilisation after 2100 . Radiative forcing is a measure of the influence a factor has in altering the balance of incoming and outgoing energy in the Earth-atmosphere system and is an index of the importance of the factor as a potential climate change mechanism. The radiative forcing values are for changes relative to preindustrial conditions defined at 1750 and are expresses in Watts per square meter (W/m2) (IPCC, 2007).

15 This study does not cover climate change variables, such as salinization, lost coast, CO2 level and increased drought.

16 The GSSE sub category H. Agricultural knowledge and innovation system is abbreviated to agricultural knowledge and the sub-category J. Development and maintenance of rural infrastructure. GSSE data covers rice and other crops. Therefore, these GSSE data were divided by the rice production value ratio of total agricultural production value in each country/region and each year. Agricultural production value data are derived from FAOSTAT (FAO, 2018). As for EU28, the rice ratio in Italy is applied for Japonica rice production, and the rice ratio in Spain is applied for Indica rice production. These data indicate as the amount of investment value for Indica and Japonica rice. GSSE covers China, Japan, Korea, United States, EU28, Viet Nam, and the Philippines. However, it does not cover other countries, and herefore FAOSTAT data is applied for the other countries.
}

${ }^{17}$ Land development is the result of actions leading to major improvements in land quantity, quality, or productivity, or which prevent its deterioration. The data are derived from FAOSTAT (FAO, 2018).

${ }^{18}$ The growth rate of investments in agricultural knowledge and innovation system, and development and maintenance of infrastructure in the Philippines from 2010 to 2017 was $12.9 \%$ and $17.0 \%$ on average. This seems too high, so we apply the growth rates from 2014 to 2017 for the Philippines to the baseline outlook period. 
The climate variables (minimum and maximum temperatures, and precipitation) in each country and region are exogenous to the model, and all climate variables for both the baseline and Representation Concentration Pathways (RCP) scenarios in this study are derived from future climate change projections made by the Model for Interdisciplinary Research on Climate (MIROC), a global climate model under the RCP 4.5 scenario. ${ }^{19}$ The RCP 4.5 scenario denotes an intermediate emission scenario among all RCP scenarios. Therefore, this study applies the RCP 4.5 scenario's climate conditions to the climate change assumption for the baseline. ${ }^{20}$ Spatially averaged climate variables for each country are computed in the same manner as the historical climate data used for regression estimation. The standard deviations of the minimum and maximum temperatures and precipitation are projected to increase from the decades of 1980-2009 to 2015-2040 in most target areas and countries based on the above climate conditions (Koizumi and Furuhashi, 2020).

This study applies agricultural investment data as agricultural knowledge and infrastructure derived from the OECD's General Service Support Estimates (GSSE) to China, Japan, Korea, United States, EU28, Viet Nam, and the Philippines (OECD, 2019). ${ }^{21}$ Land development and agricultural machinery and equipment estimates are applied to the other developing countries. ${ }^{22}$ We assume that the current growth rates of investments in agricultural knowledge and innovation systems and development and maintenance of infrastructure from 2010 to 2017 continue for the projection period (2015/17-2040) (Table 4). ${ }^{23}$ We also assume that the growth rates of investment in agricultural machinery \& equipment and land development from 2000 to 2007 in the other developing counties, based on information available on FAOSTAT, will continue for the projection period. These are all in real terms and deflated with each country and region's CPI. The annual CPI data are obtained from the IMF's International Financial Statistics (IMF, 2019).

This study examines the impact of agricultural investment on world Indica and Japonica rice markets. It compares the baseline with six scenarios, all of which assume that investments in agricultural knowledge or in infrastructure will have a zero annual growth rate over the projection period. The scenarios focus on three countries with a higher share of agricultural investment: Viet Nam, the Philippines, and China (Table 4). As this study focuses on the OECD-based agricultural investments impact on world Indica and Japonica rice price stability, it does not target scenario simulation for FAO-based land development and agricultural machinery and equipment in other countries.

\footnotetext{
${ }^{19}$ RCPs are time and space dependent trajectories of concentrations of greenhouse gases and pollutants resulting from human activities, including changes in land use. RCP 4.5 is defined as stabilisation without an overshoot pathway to $4.5 \mathrm{~W} / \mathrm{m} 2$ at stabilisation after 2100 . Radiative forcing is a measure of the influence a factor has in altering the balance of incoming and outgoing energy in the Earth-atmosphere system and is an index of the importance of the factor as a potential climate change mechanism. The radiative forcing values are for changes relative to preindustrial conditions defined at 1750 and are expresses in Watts per square meter (W/m2) (IPCC, 2007).
}

20 This study didn't cover climate change variables such as salinization, lost coast, CO2 level and increased drought.

21 The GSSE sub category $\mathrm{H}$. Agricultural knowledge and innovation system is abbreviated to agricultural knowledge and the sub-category J. Development and maintenance of rural infrastructure. GSSE data covers rice and other crops. Therefore, these GSSE data were divided by the rice production value ratio of total agricultural production value in each country/region and each year. Agricultural production value data are derived from FAOSTAT (FAO, 2018). For EU28, the rice ratio in Italy is applied for Japonica rice production, and the rice ratio in Spain is applied for Indica rice production. These data indicate as the amount of investment value for Indica and Japonica rice. GSSE covers China, Japan, Korea, United States, EU28, Viet Nam, and the Philippines. However, it does not cover other countries, and therefore FAOSTAT data is applied to the other countries.

22 Land development is the result of actions leading to major improvements in land quantity, quality, or productivity, or which prevent its deterioration. The data are derived from FAOSTAT (FAO, 2018).

23 The growth rate of investments in agricultural knowledge and innovation system, and development and maintenance of infrastructure in the Philippines from 2010 to 2017 was $12.9 \%$ and $17.0 \%$ on average. This seems too high, so we applied the growth rates from 2014 to 2017 for the Philippines to the baseline outlook period. 


\section{Figure 5. Structure of the RECC model for the Japonica rice market}

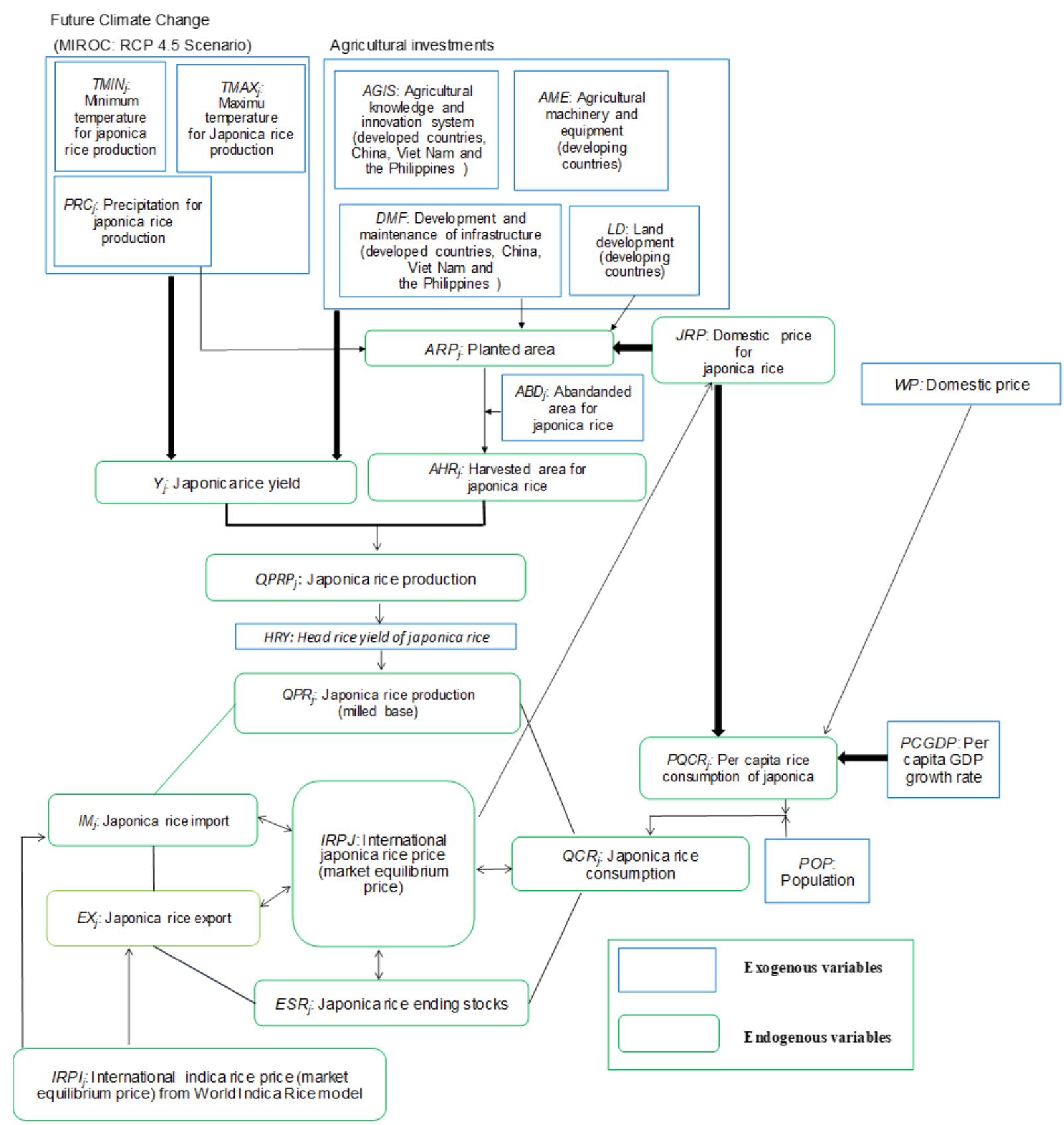

Source: Koizumi and Furuhashi (2020). 
Table 4. Growth rate of agricultural investments under baseline and scenario assumptions

\begin{tabular}{l|l|c|c|c}
\hline Countries or region & \multicolumn{1}{c|}{$\begin{array}{c}\text { Type of } \\
\text { General Service Support Estimates (GSSE) }\end{array}$} & $\begin{array}{c}\text { Baseline } \\
\text { annual growth rate }\end{array}$ & Scenario & $\begin{array}{c}\text { Scenario } \\
\text { annual growth rate }\end{array}$ \\
\hline United States & Agricultural knowledge (GSSE H) & $0.4 \%$ & & \\
\hline China & Infrastructure (GSSE J) & $1.7 \%$ & & $0 \%$ \\
\hline & Agricultural knowledge (GSSE H) & $4.3 \%$ & Scenario 5 & $0 \%$ \\
\hline Japan & Infrastructure (GSSE J) & $6.4 \%$ & Scenario 6 & \\
\hline & Agricultural knowledge (GSSE H) & $-2.4 \%$ & & \\
\hline Korea & Infrastructure (GSSE J) & $1.1 \%$ & & \\
\hline & Agricultural knowledge (GSSE H) & $0.1 \%$ & & $0 \%$ \\
\hline Viet Nam & Infrastructure (GSSE J) & $-1.1 \%$ & & $0 \%$ \\
\hline The Philippines & Agricultural knowledge (GSSE H) & $6.4 \%$ & Scenario 1 & \\
\hline & Infrastructure (GSSE J) & $6.7 \%$ & Scenario 2 & \\
\hline EU28 & Agricultural knowledge (GSSE H) & $5.1 \%$ & Scenario 3 & $0 \%$ \\
\hline & Infrastructure (GSSE J) & $4.0 \%$ & Scenario 4 & \\
\hline & Agricultural knowledge (GSSE H) & $0.6 \%$ & & \\
\hline
\end{tabular}

Source: OECD (2019).

\section{Results}

\section{Baseline}

Under the baseline, world Indica rice production and consumption are expected to increase at $0.9 \%$, exports at $1.4 \%$, imports at $1.6 \%$, and ending stocks at $1.4 \%$ per annum over the projection period (Tables A C.1 and C.2). The international Indica rice real price is projected to increase from USD 396.9/t in 2015/17 to USD 461.1/t in 2040. The world Japonica rice production is expected to increase at $0.2 \%$, consumption at $0.4 \%$, exports and imports at $1.6 \%$, and ending stocks at $0.2 \%$ per annum during the outlook period (Tables A C.3 and C.4), while the international Japonica rice real price is projected to increase from USD 670.2/t in 2015/17 to USD 707.5/t in 2040. Future climate change is projected to have different impacts on both Indica and Japonica rice production. The coefficient of variation ${ }^{24}(\mathrm{CV})$ of international Indica rice price is 0.1083 , and the CV of international Japonica price is 0.1776 from $2015 / 17$ to 2040 . Consequently, the international Japonica rice price is more volatile than international Indica prices in the baseline projection.

\section{Major scenario results}

In Scenario 1, Indica rice production in Viet Nam is expected to decrease by $9.0 \%$ and exports by $34.0 \%$, compared to the baseline average, from 2018 to 2040 (Figure 6). Therefore, the international Indica rice price is expected to increase by $7.0 \%$. In Scenario 2, Indica rice production in Viet Nam is expected to decrease by $3.2 \%$ and exports by $12.1 \%$ from 2018 to 2040 (Figure 6). Therefore, the international Indica rice price is expected to increase by $2.4 \%$. In Scenario 3, Indica rice production in the Philippines is expected to decrease by $0.9 \%$, and imports are expected to increase by $6.0 \%$ from 2018 to 2040 (Figure 7). Therefore, the international Indica rice price is expected to increase by $0.3 \%$. In Scenario 4 , Indica rice production in the Philippines is expected to decrease by $3.9 \%$, and imports are expected to increase by

24 The coefficient of variation (CV) is a statistical measure of the dispersion of data points in a data series around the mean. CV was derived from standard deviation divided by mean. CV allows for comparing the degree of variation from one data series to another. 
$27.2 \%$, compared to the baseline average, from 2018 to 2040 (Figure 7). Accordingly, the international Indica rice price is expected to increase by $1.2 \%$. The impacts on Japonica rice markets are quite limited in these scenarios. More detailed results from Scenarios 1 to 4 are available in Table A C.5.

\section{Figure 6. Viet Nam scenarios: Impact on the Indica rice markets compared to baseline}

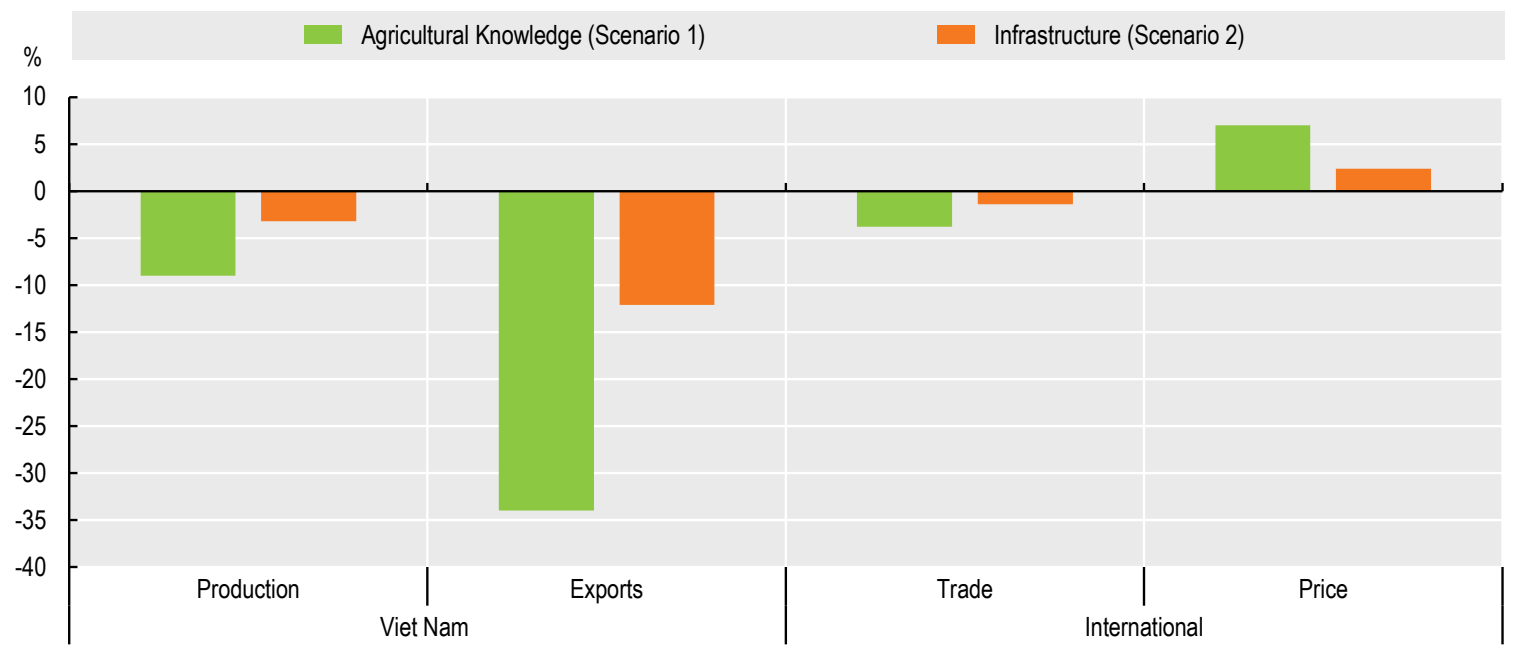

Source: Own calculations.

Figure 7. The Philippines scenarios: Impact on the Indica rice markets compared to baseline

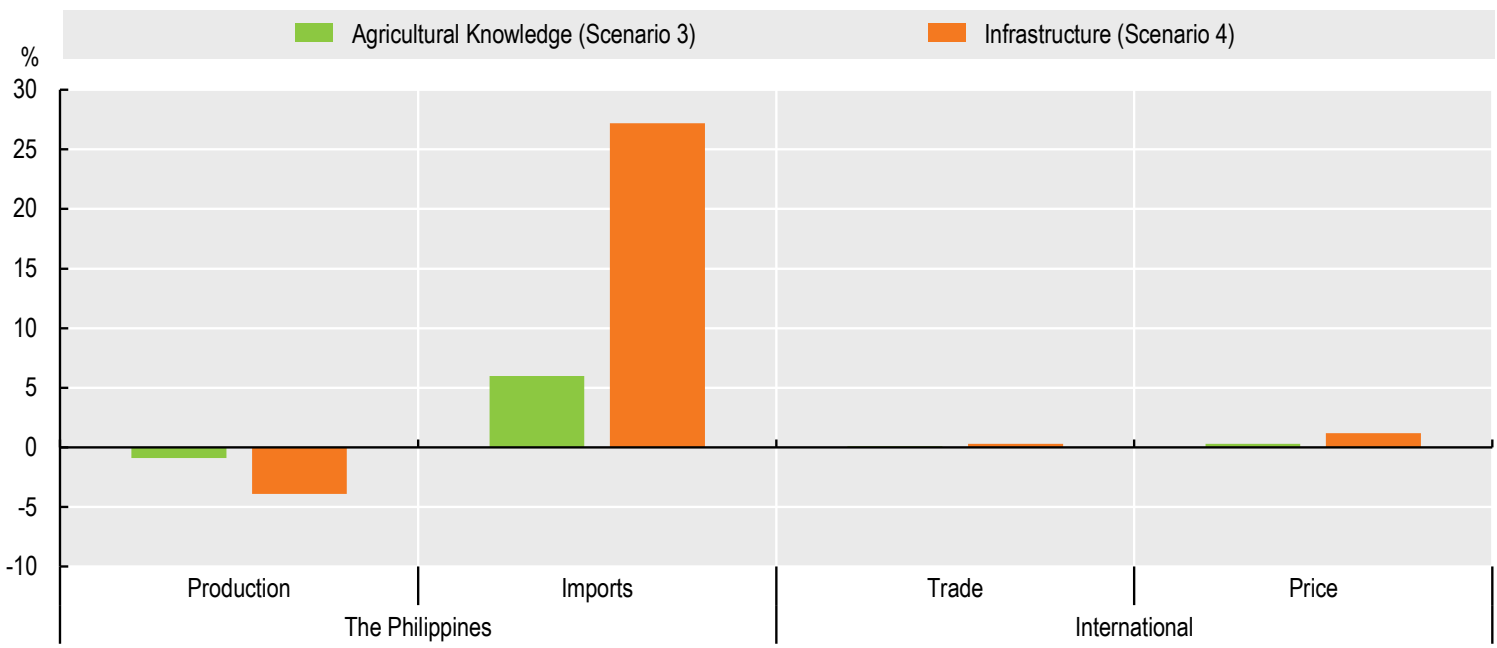

Source: Own calculations.

In Scenario 5, Indica rice production in China is expected to decrease by $1.2 \%$, and its imports are expected to increase by 19.0\%, compared to the baseline projection average, from 2018 to 2040 (Figure 8). Accordingly, the international Indica rice price is expected to increase by $2.9 \%$. Japonica rice production in China is expected to decrease by $1.0 \%$ and exports by $24.9 \%$, compared to the baseline average, from 2018 to 2040 (Figure 8). Therefore, the international Japonica rice price is expected to increase by $9.9 \%$. In Scenario 6, Indica rice production in China is expected to decrease by $1.3 \%$, and its imports are expected to increase by $19.7 \%$ (Figure 8) from 2018 to 2040. Accordingly, the international Indica rice price is expected to increase by $2.9 \%$. Japonica rice production in China is expected to decrease by $0.7 \%$ 
and exports are expected to decrease by $17.5 \%$ from 2018 to 2040 (Figure 8 ). Therefore, the international Japonica rice price is expected to increase by $6.8 \%$. For more detailed results from Scenarios 5 and 6 , please refer to Table A C.6.

\section{Figure 8. China scenarios: Impact on the Japonia and Indica rice markets}

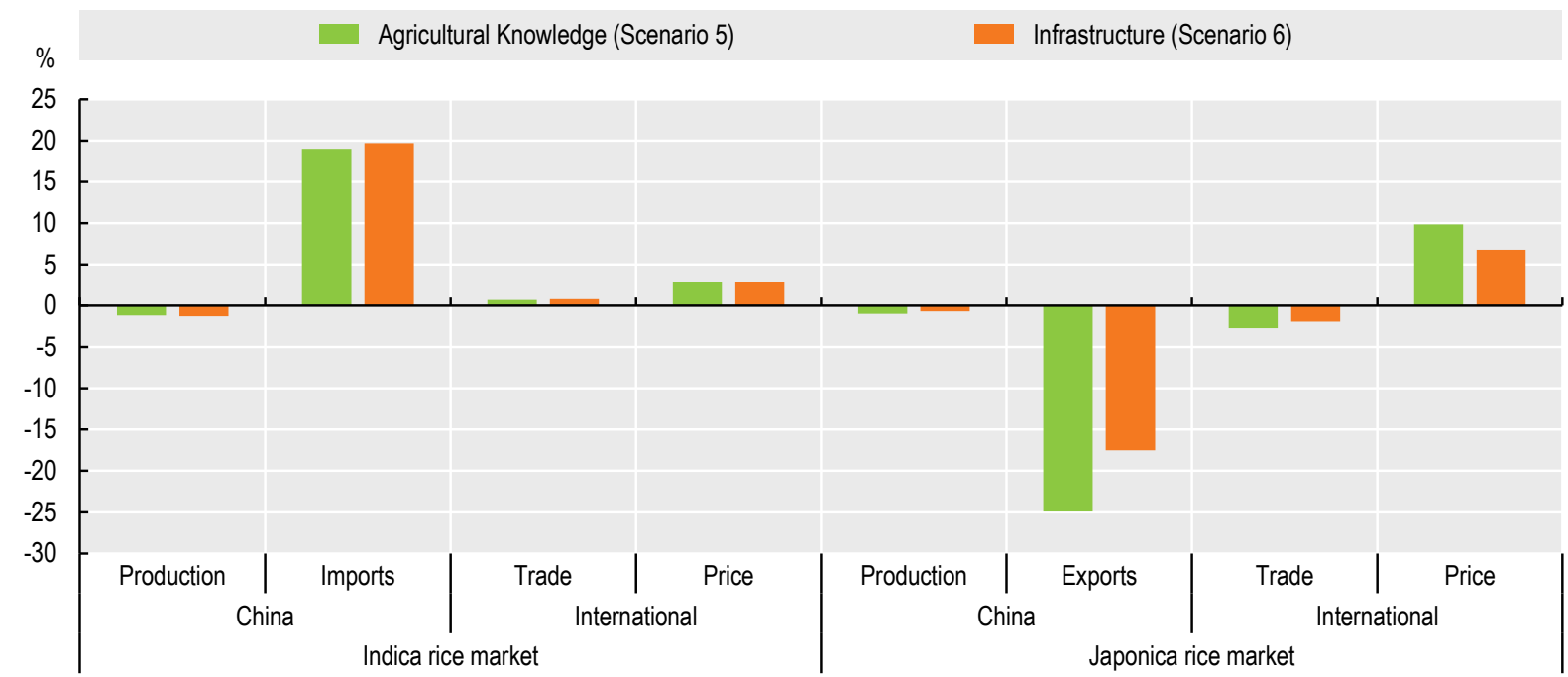

Source: Own calculations.

As expected, the reduction of agricultural investment increases the international Indica and Japonica rice prices (Table A.C 7), and the variation measured in CVs increases in all scenarios (Figure 9). The impact of a reduction of investment in agricultural knowledge in Viet Nam (Scenario 1) is the most significant factor stabilising the international Indica rice price of the compared scenarios. Viet Nam is the major Indica rice exporter and is expected to account for $17.4 \%$ of global Indica exports in 2040 in the baseline projection, having a higher share of Indica rice exports than other scenario countries. The projected increase in investment in agricultural knowledge or infrastructure in Viet Nam are higher than for other Indica rice producing countries. Furthermore, results from the regression analysis show that the magnitude of linkage of investment in agricultural knowledge is higher than that of investment in infrastructure in the Indica rice yield equation of Viet Nam (Table A B.1). This explains the more significant impact of investment in agricultural knowledge in Viet Nam (Scenario 1) on the global Indica rice market as compared to the other scenarios.

Accordingly, the CVs of the international Japonica rice price from 2015-2017 to 2040 in all scenarios are higher than those in the baseline (Figure 9). China is the largest Japonica rice producer and exporter; it is expected to account for $68.3 \%$ of total Japonica production and for $24.6 \%$ of total Japonica exports in 2040 in the baseline projection. In China, the rate of change of investment in infrastructure in the baseline projection is higher than the rate of change in agricultural knowledge. However, the parameter estimations show that investments in agricultural knowledge in China have more than twice the impact of investments in infrastructure on Japonica rice yields (Table A B.2). This explains why agricultural knowledge in China (Scenario 5) had the largest impact on the global Japonica rice market compared to all other scenarios. Consequently, investment in agricultural knowledge in China is the most crucial factor stabilising the international Japonica rice price in all compared scenarios. 
Figure 9. Coefficient of variation for Indica and Japonica prices

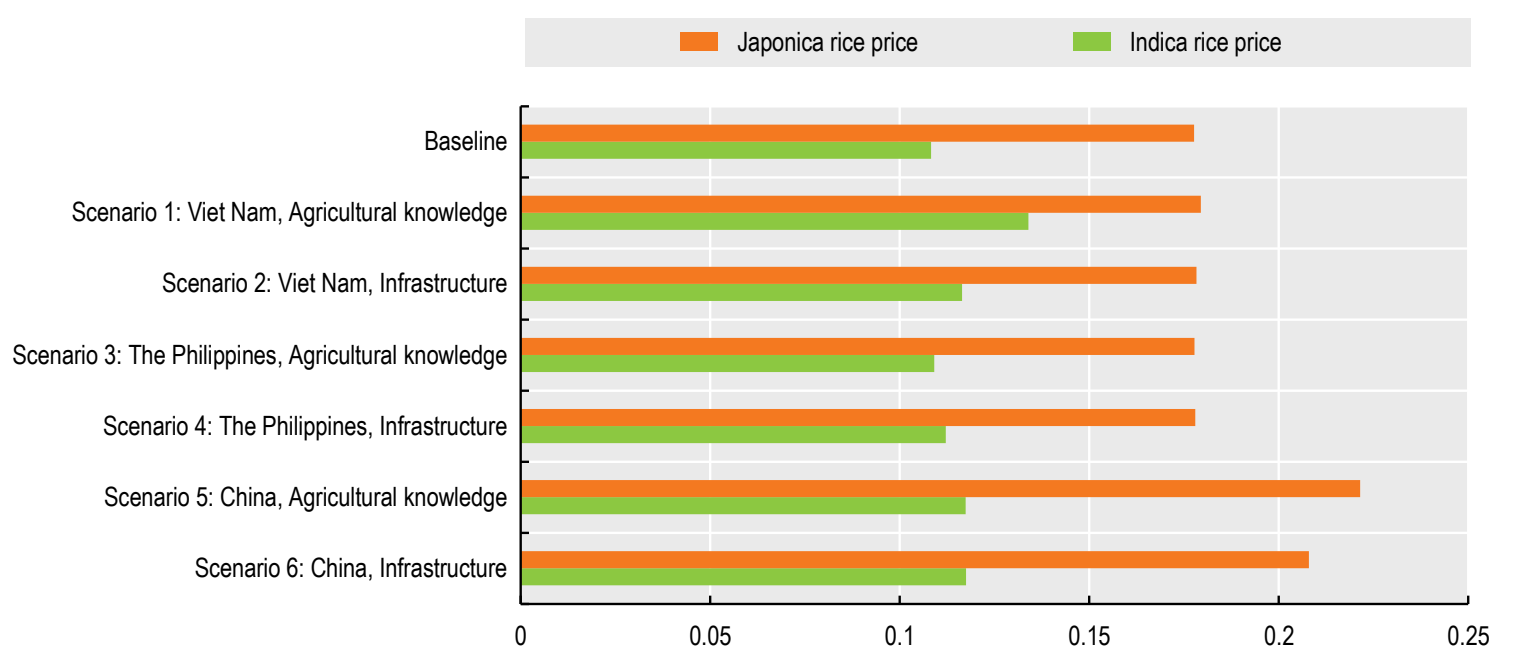

\section{Conclusions}

The differences in the Indica and Japonica rice market structures appear to be based on the differences in their characteristics, production zones, consumer preferences, and government policies. Among these, strong consumer preference is the most crucial factor that distinguishes the two market structures, as there is little substitution between Indica and Japonica rice consumption. Rice policies impact on both rice markets. Most of the Japonica producing countries have higher protective policy measures than those of Indica producing countries, based on the result of OECD Agricultural Policy Monitoring and Evaluation (OECD, 2020).

Most agricultural commodity models do not distinguish between Indica and Japonica rice markets, although this study documents that these have different structures. On the other hand, the separation of market data for rice varieties is based often on assumed information rather than on statistical data. A global Indica and Japonica model was developed, which projected and simulated the future global Indica and Japonica rice markets under climate change in the mid- to long-term. Future climate change is projected to have different impacts on both Indica and Japonica rice production. The results of the baseline and alternative simulations indicate that the international Japonica rice price is more volatile than is the one for Indica rice under possible future climate change, due to the smaller international market and higher protection policy measures

This study also examined how future agricultural investments would impact world Indica and Japonica rice markets, including price stability on the international market, based on scenarios of future climate change over the mid- to long-term. The baseline is compared with six scenarios, which assume zero growth in a specific type of agricultural investments (agricultural knowledge and innovation system, or development and maintenance of infrastructure) in individual countries (Viet Nam, the Philippines, and China). Investment in agricultural knowledge and innovation system in Viet Nam and China will play a significant role in stabilising international Indica and Japonica rice prices, respectively, in the mid-to long-term, as rice production becomes increasingly affected by climate change.

This study used limited time-series data for regression estimations in the model and covered limited agricultural investment data for its scenarios because of the challenge in obtaining reliable time-series data 
for longer periods of time in each country. More time-series data for the analysis of both types of rice and the agricultural investment incorporated in the model could constitute future areas of study.

The most important cause for different market developments is consumer preference of specific characteristics. Distinguishing between Indica and Japonica rice can assist in analysing specific questions related to rice markets. Simulations indicate that the international Japonica rice price is more volatile than it is for Indica rice under possible climate change scenarios. The simulation results suggest that agricultural investments in major Indica and Japonica rice-producing countries would contribute to price stability in the mid- to long-term under climate change. Depending on the focus of the assessment, further separation of rice markets may be applied, for example between irrigated and non-irrigated production or separating aromatic rice varieties.

The methods used for this study mean that its results are inconclusive as to whether Indica and Japanoica markets should be treated separately in consumption; a wider range of methods needs to be explored. Future studies should focus on the potential for farmers to substitute between rice varieties when making production decisions and to explore the policy settings required to enable this flexibility. Substitution in production is likely to be a critical factor underpinning regional food security. 


\section{References}

ASEAN Food Security information System (AFSIS) (2016), ASEAN Agricultural Commodity Outlook, No.15, pp.90.

Calingacion, M. et al. (2014), Diversity of Global Rice markets and the Science Required for Consumer Targeted Rice Breeding, PLOS One, Volume 9, Issue 1, pp. 1-12.

Calpe, C. (2006), Rice international commodity profile, Market and Trade Division, Food and Agricultural Organization of the United Nations, http://www.fao.org/fileadmin/templates/est/COMM MARKETS MONITORING /Rice/Documents/Rice_Profile_Dec-06.pdf.

China National Statistical Bureau and the China National Grain and Oils Information Center (2018), Statistics, http://www.grain.gov.cn/ (in Chinese))

Climate Research Unit (CRU) of the University of East Anglia. Time-series datasets of variations in climate with variations in other phenomena, http://catalogue.ceda.ac.uk/uuid/3f8944800cc48e1cbc29a5ee12d8542d

Dawe, D. and Slayton, T. (2010), The World Rice market Crisis of 2007-2008, The Rice Crisis, pp.15-28.

European Commission (2018a), Cereals, oilseeds, protein crops and rice, https://ec.europa.eu/info/foodfarming-fisheries/plants-and-plant-products/plant-products/cereals en.

European Commission (2018b), Eurostat, https://ec.europa.eu/eurostat/web/international-trade-ingoods/data

European Commission (2020), Cereals, oilseeds, protein crops and rice, https://ec.europa.eu/info/foodfarming-fisheries/plants-and-plant-products/plant-products/cereals en.

Falcon, P.W. and Monke, E.A.(1980) "International Trade in Rice", Food Research Institution Studies, XV II , No.3, pp.279-306.

FAO (2018), FAOSTAT, http://www.fao.org/faostat/en/\#home

Global Tarde Atlas (2019), International Import and Export Commodity Trade data, https://ihsmarkit.com/products/maritime-global-trade-atlas.html.

International Monetary Fund (IMF) (2018), World Economic Outlook Database, https://www.imf.org/external/pubs/ft/weo/2018/02/weodata/index.aspx.

International Monetary Fund (IMF) (2019), International Financial Statistics. https://data.imf.org/?sk=4FFB52B2-3653-409A-B471-D47B46D904B5.

International Monetary Fund (IMF) (2020), Primary Commodity Prices, https://www.imf.org/en/Research/commodity-prices

International Panel on Climate Change (IPCC) (2007), Radiative forcing, https://www.ipcc.ch/report/ar4/syr/.

International Rice Research Institute (IRRI) (2019), Physical quality of milled rice, http://www.knowledgebank.irri.org/training/fact-sheets/postharvest-management/rice-quality-factsheet-category/item/physical-quality-of-milled-rice-fact-sheet.

Ishitani, K.(1993), "Characteristics of Japanese rice and development of new rice", Cooking Science, 26, pp.85-92.

Ito, S. (2010), "Japans Rice Policy and its Role in the World Rice Markets: Japan Should Act as a Watchdog”, The Rice Crisis, Markets, Policies and Food Security, pp.299-312.

Ito, S. (2015), World Japonica rice market and international competitiveness of Japanese rice, Nourintoukei kyokai (Japanese), pp.3-36. 
John, A. (2014), "Price relations between international rice markets", Agricultural and Food Economics, 2(1), pp.1-16.

Kato, S. and Maruyama, Y. (1928), "Serodiagnostic Investigation on the Affinities of Different Varieties of Rice", Science bulletin of the Faculty of Agriculture, Kyushu University, 3(1), pp. 16-29.

Koizumi, T. and Furuhashi, T. (2020), "Global Rice Market Projections Distinguishing Japonica and Indica Rice under Climate Change", JARQ, 54(1), 63-91.

Lee, J.S. et al. (2018), "Genetic relationship of tropical region-bred temperate japonica rice (Oryza sative) plants and their grain yield variations in three different tropical environments", Plant Breeding, 137(8), 857-864.

Ministry of Agriculture, Forestry and Fisheries, Japan (MAFF) (2014), Japonica rice production and distribution in China, http://www.maff.go.jp///kokusai/kokusei/kaigai nogyo/k syokuryo/pdf/h25asiachina2.pdf.

Ministry of Agriculture, Forestry and Fisheries, Japan (MAFF) (2018), Rice Export and Import, http://www.maff.go.jp/j/council/seisaku/syokuryo/181128/attach/pdf/re data 3-7.pdf.

Mizuno, H. (2015), "The Postharvest Technical Present Conditions in Thailand Rice”, Journal of Japanese Society of Agricultural Machinery and Food Engineers, Vol.77(5), pp.317-321.

Morishita, H. and Oka, H. (1981), "Phylogenetic Differentiation of cultivated Rice, XX II . Numerical Evaluation of the Indica-Japonica Differentiation", Japan Journal of Breed, 31(4), pp.402-413.

National Bureau of Statistics of China (2017), Chinese Statistical Yearbook 2017, National Bureau of Statistics of China.

National Development and Reform Commission (2019), Notice on the publication of the minimum purchase price of rise in 2019. http://zfxxgk.ndrc.gov.cn/web/iteminfo.jsp?id=16112

OECD (2018), OECD Economic Outlook No.144, https://www.oecd.org/eco/outlook/economic-outlooknovember- 2018/.

OECD (2019), General Service Support Estimates (GSSE), https://stats.oecd.org/glossary/detail.asp?ID $=1100$.

OECD-FAO (2018), OECD-FAO Agricultural Outlook 2018-2027, Cereals, http://www.fao.org/3/i9166e/i9166e Chapter3 Cereals.pdf.

OECD-FAO (2019), OECD-FAO Agricultural Outlook 2019-2028, http://www.fao.org/3/ca4076en/ca4076en.pdf.

OECD-FAO (2020), OECD-FAO Agricultural Outlook 2020-2029, https://www.oecd.org/publications/oecd-fao-agricultural-outlook-19991142.htm

OECD (2020), Agricultural Policy Monitoring and Evaluation 2020, OECD Publishing, Paris, https://doi.org/10.1787/928181a8-en.

Oka, H. (1953), "Phylogenetic differentiation of cultivated rice, Variation in various characters and character combinations among rice varieties". Japan Journal of Breed, 3, pp. 33-43.

Petzel, T.E. and Monke E.A. (1980), "The integration of the international Rice Market", Food Research Institute Studies, 17(3), pp.307-326.

Rastegari-Henneberry, S. (1985), "The World Rice Market”, Giannini Foundation Information Series, No.85-2, University of California.

Siamwalla, A. and Haykin, S. (1983), "The World Rice Market: Structure, conduct and Performance", International food Policy Research Institute, Research Report 39, pp.1-84.

Soon, B.M.et al. (2019), "The impact of Potential Korea-U.S. Free Trade Agreement Renegotiation on the Korean Rice Market and Trade", Journal of Agricultural and Applied Economics, 51, pp.434-449.

United Nations, Department of Economics and Social Affairs (2017), World Population Prospects, the 2017 Revision, http://esa.un.org/unpd/wpp/. 
United Nations, Statistics Division (2018), UN Comrade Database - International Trade Statistics, Import/Export Data, http://comtrade.un.org/

United States Department of Agriculture, Economic Research Service (USDA-ERS) (2012), Rice Outlook, https://www.ers.usda.gov/publications/pub-details/?pubid=38520.

United States Department of Agriculture, Economic Research Service (USDA-ERS) (2018), Rice Yearbook, https://www.ers.usda.gov/data-products/rice-yearbook/

United States Department of Agriculture, Economic Research Service (USDA-ERS) (2020), Rice Yearbook, https://www.ers.usda.gov/data-products/rice-yearbook/

United States Department of Agriculture, Foreign Agricultural Service (USDA-FAS), Grain and Feed reports, Japan, Gain series, https://gain.fas.usda.gov/\#/search.

United States Department of Agriculture, Foreign Agricultural Service (USDA-FAS) (2018a), Global Agricultural Trade System, Standard Query, https://apps.fas.usda.gov/gats/default.aspx.

United States Department of Agriculture, Foreign Agricultural Service (USDA-FAS) (2018b), PS\&D, https://apps.fas.usda.gov/psdonline/app/index.html\#/app/home

United States Department of Agriculture, National Agricultural Statistics Service (USDA- NASS) (2018), Data \& Statistics, Statistics by State, California Field Office, https://www.nass.usda.gov/Statistics by State/.

Wailes E, J and Chavez, E. (2011), Updated Arkansas Global Rice Model, https://core.ac.uk/download/pdf/6833376.pdf 


\section{Annex A. Equations for rice production and consumption}

The Japonica and Indica rice yield equations depend on the annual averages of minimum and maximum temperatures, precipitation, and lagged agricultural investments (Equation 1).

$$
\begin{aligned}
& \ln \left(Y_{v, t, c} / Y_{v, t-1, c}\right)=\mathrm{a} 1 \ln \left(T M I N_{v, t, c} / T M I N_{v, t-1, c}\right)+\mathrm{a} 2 \ln \left(T M A X_{v, t, c} / T M A X_{v, t-1, c}\right)+\mathrm{a} 3 \ln \\
& \left(P R C_{v, t, c} / P R C_{v, t-1, c}\right)+\mathrm{a} 4 \ln \left(A G I S_{t-1, c} / A G I S_{t-2, c}\right)+\mathrm{a} 5 \ln \left(D M F_{t-1, c} / D M F_{t-2, c}\right)+\mathrm{a} 6 \ln \\
& \left(L D_{t-1, c} / L D_{t-2, c}\right)+\mathrm{a} 7 \ln \left(A M E_{t-1, c} / A M E_{t-2, c}\right)
\end{aligned}
$$

where $Y$ is paddy rice yield, TMIN is minimum temperature, TMAX is maximum temperature, $P R C$ is precipitation, $A G I S$ is investment amount of agricultural knowledge and innovation system, $D M F$ is that of development and maintenance of infrastructure, $L D$ denotes investments in land development, $A M E$ denotes investments in agricultural machinery/equipment ${ }^{25}, v$ is rice varieties (Japonica or Indica), $t$ is time, $c$ are countries/region and $a 1-a 7$ are parameters. Tables A B.1 and A B.2 list these estimated parameters.

The planted area equations for Japonica and Indica rice depend on the lagged domestic prices of Japonica and Indica rice, lagged price of wheat, lagged precipitation, and lagged agricultural investments (Equation 2).

$$
\begin{aligned}
& \ln \left(A P R_{v, t, c} / A P R_{v, t-1, c}\right)=\mathrm{a} 8 \ln \left(J R P_{t-1, c} / J R P_{t-2, c}\right)+\mathrm{a} 9 \ln \left(I R P_{t-1, c} / I R P_{t-2, c}\right)+\mathrm{a} 10 \ln \\
& \left(W P_{t-1, c} / W P_{t-2, c}\right)+\mathrm{a} 11 \ln \left(P R C_{v, t, c} / P R C_{v, t-1, c}\right)+\mathrm{a} 12 \ln \left(D M F_{t-1, c} / D M F_{t-2, c}\right)+ \\
& \text { a13 } \ln \left(L D_{t-1, c} / L D_{t-2, c}\right)
\end{aligned}
$$

where $A P R$ is the planted area of rice, $J R P$ is the domestic price for Japonica rice, IRP is domestic price for Indica rice ${ }^{26}, W P$ is the domestic price for wheat, a8-13 are other parameters. Tables A B.3 and B.4 list these estimated parameters. ${ }^{27}$

\footnotetext{
${ }^{25}$ Minimum temperature, maximum temperature and precipitation are based on the Japonica and Indica rice growing location. Therefore, they are distinguished by Japonica and Indica rice varieties. Agricultural knowledge and innovation system, development and maintenance of infrastructure, investments in land developing, investments in agricultural machinery/equipment are not distinguished by Japonica and Indica varieties due to data limitation.

26 These domestic prices are derived from the China Statistical Year book (National Bureau of Statistics of China, 2017), Cereals, oilseeds, protein, crops and rice (European Commission, 2018a), Rice Yearbook (USDA-ERS, 2018) and FAOSTAT (FAO, 2018).

27 Please refer to Koizumi and Furuhashi (2020). Dummy variables are used utilised for political factors (such as sudden rice program change, rice export restriction and others), financial speculative factors and other external factors impacted on rice markets. The harvested areas of Indica and Japonica rice are derived from the difference between the planted area and abandoned area. The abandoned area is an exogenous variable and will be utilised for simulation in future studies. We assume that the abandoned area is set to zero in all countries during the projection period.
} 
$A H R_{v, t, c}=A P R_{v, t, c}-A B D_{v, t, c}$

where $A H W$ is harvested area and $A B D$ is abandoned area.

$Q P R_{v, t, c}=A H R_{v, t, c}{ }^{*} Y_{v, t, c}$

where $Q P R$ denotes rice production.

Both rice consumption are calculated by multiplying the per capita rice consumption by the country's population (Equation 5). Per capita rice consumption of japonica and indica types depends on the income, domestic prices for japonica and indica rice, and wheat prices (Equation 6).

$$
Q C R_{v, t, c}=P Q C R_{v, t, c}{ }^{*} P O P_{t, c}
$$

where $Q C R$ represents rice consumption and $P O P$ represents population.

$$
\begin{aligned}
& \text { In }\left(P Q C R_{v, t, c} / P Q C R_{v, t-1, c}\right)=\mathrm{a} 14 \ln \left(P C G D P_{t, d} / P C G D P_{t-1, c}\right)+\mathrm{a} 15 \ln \left(J R P_{t, c} / J R P_{t-1, c}\right) \\
& +\mathrm{a} 16 \ln \left(I R P_{t, c} / I R P_{t-1, c}\right)+\mathrm{a} 17 \ln \left(W P_{t, c} d W P_{t-1, c}\right)
\end{aligned}
$$

where $P Q C R$ is the per capita consumption of japonica and indica rice, $P C G D P$ is the per capita GDP,WP is the domestic wheat price, and a14-a17 are parameters. Tables A.B-5 and B-6 list these estimated parameters. 


\section{Annex B. Parameters for major countries and region}

Table A B.1. Estimation of parameters for Indica rice yields in major producing countries

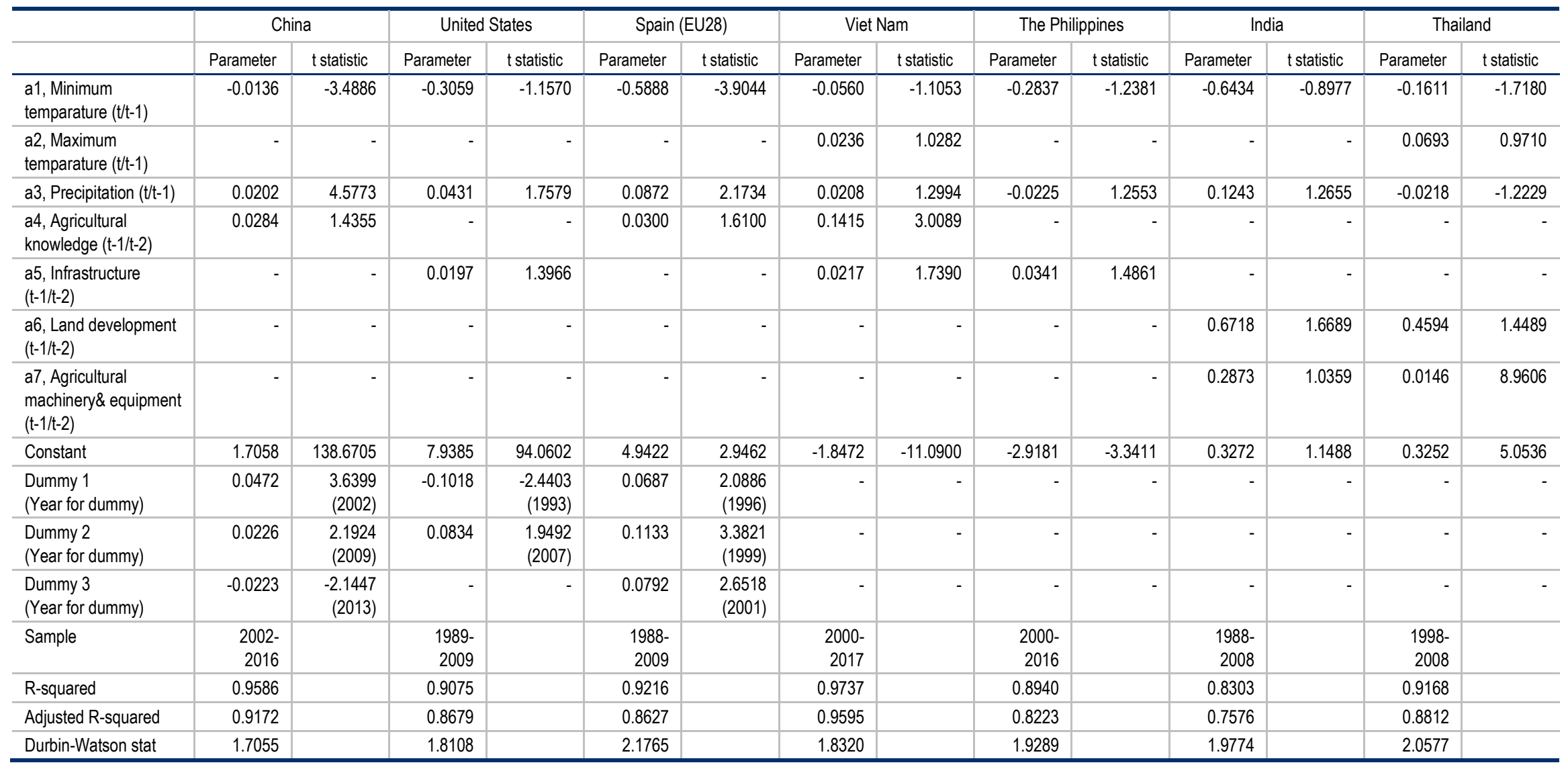

Note: Each dummy year is utilised for excluding political, speculative and other factors impacted on rice markets. 
Table A B.2. Estimation of parameters for Japonica rice yields

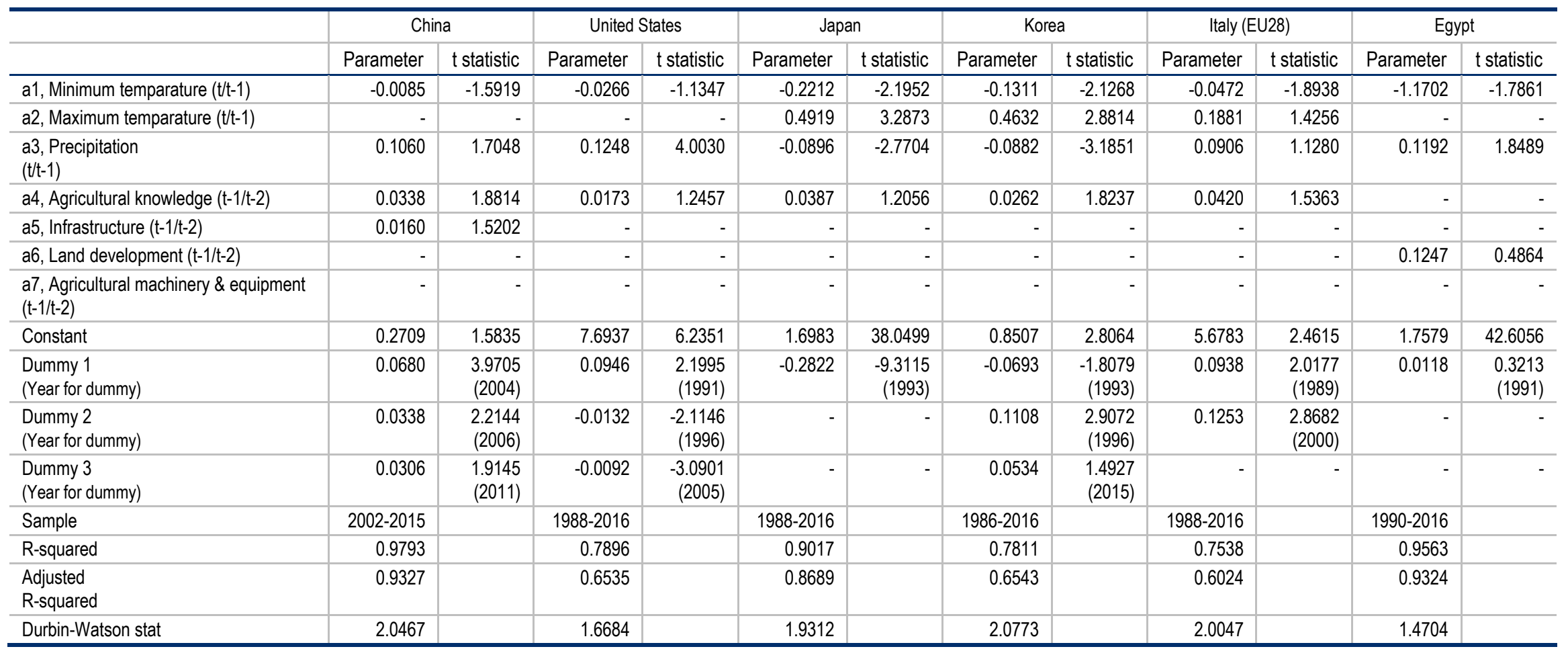

Note: Each dummy year is utilised for excluding political, speculative and other factors impacted on rice markets. 
Table A B.3. Estimation of parameters for Indica rice planted areas in major producing countries

\begin{tabular}{|c|c|c|c|c|c|c|c|c|c|c|c|c|c|c|}
\hline & \multicolumn{2}{|c|}{ China } & \multicolumn{2}{|c|}{ United States } & \multicolumn{2}{|c|}{ Spain (EU28) } & \multicolumn{2}{|c|}{ Viet Nam } & \multicolumn{2}{|c|}{ The Philippines } & \multicolumn{2}{|c|}{ India } & \multicolumn{2}{|c|}{ Thailand } \\
\hline & Parameter & $\begin{array}{c}\mathrm{t} \\
\text { statistic }\end{array}$ & $\begin{array}{c}\text { Paramete } \\
r\end{array}$ & t statistic & $\begin{array}{c}\text { Paramete } \\
r\end{array}$ & t statistic & $\begin{array}{c}\text { Paramete } \\
r\end{array}$ & t statistic & $\begin{array}{c}\text { Paramete } \\
r\end{array}$ & t statistic & $\begin{array}{c}\text { Paramete } \\
r\end{array}$ & t statistic & $\begin{array}{c}\text { Paramete } \\
r\end{array}$ & t statistic \\
\hline $\begin{array}{l}\text { a8, Domestic Japonica } \\
\text { rice price } \\
\text { (t-1/t-2) }\end{array}$ & - & - & - & - & - & - & - & - & - & - & - & - & - & - \\
\hline $\begin{array}{l}\text { a9, Domestic Indica } \\
\text { rice price (t-1/t-2) }\end{array}$ & 0.0534 & 6.7350 & 0.2006 & 2.5083 & 0.3179 & 4.6338 & 0.0103 & 1.2630 & 0.0422 & -1.2381 & 0.0780 & 2.9657 & 0.0119 & 1.5599 \\
\hline $\begin{array}{l}\text { a10, Domestic wheat } \\
\text { price (t-1/t-2) }\end{array}$ & - & - & - & - & -0.2567 & -2.7875 & - & - & - & - & -0.0230 & -0.9719 & - & - \\
\hline $\begin{array}{l}\text { a11, Precipitation } \\
(\mathrm{t}-1 / \mathrm{t}-2)\end{array}$ & 0.0113 & 5.9696 & 0.3180 & 4.4243 & 0.1681 & 2.3952 & -0.1158 & -2.6917 & -0.0249 & -1.9697 & 0.0322 & 0.6852 & -0.1671 & -2.8625 \\
\hline $\begin{array}{l}\text { a12, Infrastructure } \\
\text { (t-1/t-2) }\end{array}$ & 0.0203 & 2.3380 & 0.0586 & 4.7911 & 0.0916 & 1.8861 & 0.0231 & 1.9537 & 0.0584 & 1.3989 & - & - & - & - \\
\hline $\begin{array}{l}\text { a13, Land } \\
\text { development (t-1/t-2) }\end{array}$ & & - & & & & - & - & - & - & - & 0.7178 & 1.8989 & 0.8361 & 1.0718 \\
\hline $\begin{array}{l}\text { a14, Agricultural } \\
\text { knowledge (t-1/t-2) }\end{array}$ & - & - & - & - & & - & - & - & 0.0157 & 1.5568 & - & - & - & - \\
\hline Constant & 6.2608 & 9.6184 & 3.5982 & 2.0112 & 1.2137 & 5.2479 & 8.8668 & 841.7210 & 7.1418 & 12.9773 & 9.9797 & 50.7900 & 9.0150 & 82.1580 \\
\hline $\begin{array}{l}\text { Dummy } 1 \\
\text { (Year for dummy) }\end{array}$ & -0.8025 & $\begin{array}{r}-2.5460 \\
(2004)\end{array}$ & -0.1343 & $\begin{array}{r}-2.7169 \\
(1996)\end{array}$ & -0.8025 & $\begin{array}{r}-13.7030 \\
(1993)\end{array}$ & - & - & - & - & -0.0697 & $\begin{array}{r}-3.1316 \\
(1982)\end{array}$ & - & - \\
\hline $\begin{array}{l}\text { Dummy } 2 \\
\text { (Year for dummy) }\end{array}$ & -0.2525 & $\begin{array}{r}-1.0200 \\
(2006)\end{array}$ & 0.1690 & $\begin{array}{l}3.6979 \\
(1999)\end{array}$ & -0.2525 & $\begin{array}{r}-4.3355 \\
(1995)\end{array}$ & - & - & - & - & 0.0320 & $\begin{array}{l}1.4605 \\
(1991)\end{array}$ & - & - \\
\hline $\begin{array}{l}\text { Dummy } 3 \\
\text { (Year for dummy) }\end{array}$ & 0.0941 & $\begin{array}{l}1.8521 \\
(2013)\end{array}$ & -0.1684 & $\begin{array}{r}-2.4798 \\
(2008)\end{array}$ & 0.0941 & $\begin{array}{l}1.6073 \\
(2007)\end{array}$ & - & - & - & - & 0.0452 & $\begin{array}{l}2.0016 \\
(2002)\end{array}$ & - & - \\
\hline $\begin{array}{l}\text { Dummy } 4 \\
\text { (Year for dummy) }\end{array}$ & - & - & - & & 0.1747 & $\begin{array}{l}3.1062 \\
(2011)\end{array}$ & - & - & - & - & - & - & - & - \\
\hline Sample & 2003-2016 & & $1991-2016$ & & 1993-2016 & & $2000-2016$ & & $2000-2016$ & & 1974-2004 & & $1989-2011$ & \\
\hline R-squared & 0.9874 & & 0.8534 & & 0.9761 & & 0.9491 & & 0.9327 & & 0.8886 & & 0.8772 & \\
\hline $\begin{array}{l}\text { Adjusted } \\
\text { R-squared }\end{array}$ & 0.9672 & & 0.7361 & & 0.9541 & & 0.8374 & & 0.8766 & & 0.8144 & & 0.8411 & \\
\hline Durbin-Watson stat & 1.7733 & & 1.7521 & & 1.9941 & & 1.8071 & & 1.9629 & & 1.7080 & & 2.3143 & \\
\hline
\end{tabular}

Note: Each dummy year is utilised for excluding political, speculative and other factors impacted on rice markets. 
Table A B.4. Estimation of parameters for Japonica rice planted area

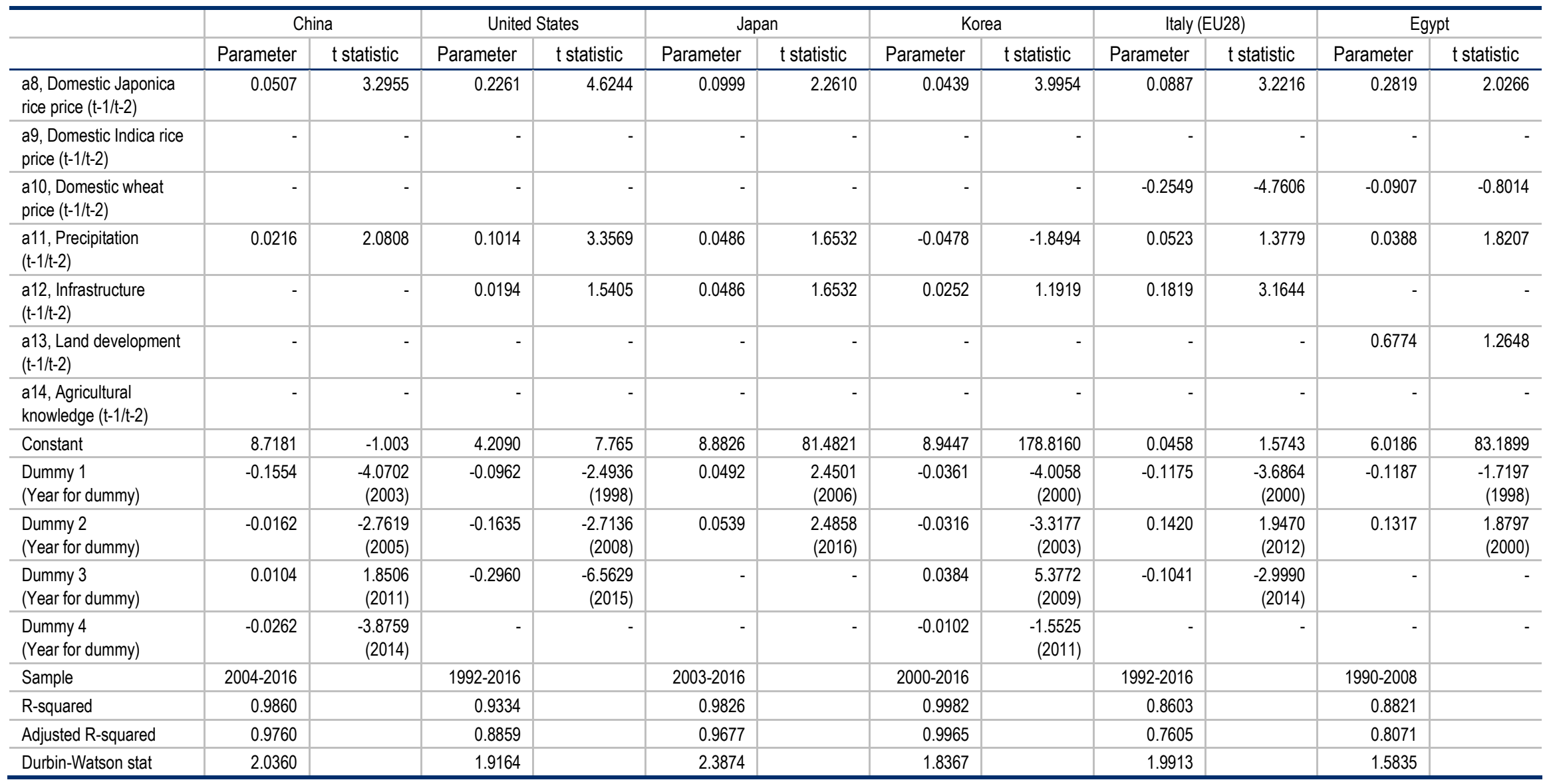

Note: Each dummy year is utilised for excluding political, speculative and other factors impacted on rice markets. 
Table A B.5. Estimation of parameters for Indica rice per capita consumption

\begin{tabular}{|c|c|c|c|c|c|c|c|c|c|c|}
\hline & \multicolumn{2}{|c|}{ China } & \multicolumn{2}{|c|}{ United States } & \multicolumn{2}{|c|}{ Japan } & \multicolumn{2}{|c|}{ Korea } & \multicolumn{2}{|c|}{ Italy (EU28) } \\
\hline & Parameter & t statistic & Parameter & t statistic & Parameter & t statistic & Parameter & t statistic & Parameter & t statistic \\
\hline a14, Income : Per capita GDP growth ratio (tt-1) & 0.1170 & 2.3536 & -0.0912 & -3.6380 & -0.8141 & -1.5025 & -0.2361 & -1.7035 & -0.3671 & -2.5647 \\
\hline a15, Domestic Japonica rice price (tt-1) & 0.0128 & 0.8964 & - & - & - & - & - & - & - & - \\
\hline a16, Domestic Indica rice price (t/t-1) & -0.0420 & -2.4488 & -0.2199 & -2.7048 & -0.3720 & -1.4657 & -2.3627 & -4.3763 & -0.1796 & -2.5335 \\
\hline a17, Domestic Wheat price (t/t-1) & 0.0116 & 1.7024 & 0.2640 & 2.5550 & 0.3556 & 1.4891 & - & - & - & \\
\hline Constant & 1.8706 & 3.2362 & 3.7220 & 7.7816 & -0.5974 & -3.2020 & -0.7980 & -1.9167 & 0.3715 & 2.1493 \\
\hline $\begin{array}{l}\text { Dummy } 1 \\
\text { (Year for dummy) }\end{array}$ & 0.0299 & $\begin{array}{l}2.4584 \\
(2001)\end{array}$ & 0.1891 & $\begin{array}{l}3.0103 \\
(2005)\end{array}$ & 1.0281 & $\begin{array}{l}4.3274 \\
(1999)\end{array}$ & -0.4674 & $\begin{array}{r}-1.5572 \\
(2007)\end{array}$ & -0.0108 & $\begin{array}{r}-0.1967 \\
(2007)\end{array}$ \\
\hline $\begin{array}{l}\text { Dummy } 2 \\
\text { (Year for dummy) }\end{array}$ & -0.0217 & $\begin{array}{r}-2.0447 \\
(2005)\end{array}$ & -0.1874 & $\begin{array}{r}-2.5781 \\
(2011)\end{array}$ & -0.2371 & $\begin{array}{r}-1.3736 \\
(2001)\end{array}$ & 0.7664 & $\begin{array}{l}2.5008 \\
(2011)\end{array}$ & -0.0506 & $\begin{array}{r}-1.8034 \\
(2010)\end{array}$ \\
\hline $\begin{array}{l}\text { Dummy } 3 \\
\text { (Year for dummy) }\end{array}$ & -0.0380 & $\begin{array}{r}-3.4855 \\
(2006)\end{array}$ & 0.2047 & $\begin{array}{l}3.0002 \\
(2014)\end{array}$ & 0.6172 & $\begin{array}{l}2.6537 \\
(2005)\end{array}$ & 1.7962 & $\begin{array}{l}6.2948 \\
(2012)\end{array}$ & & \\
\hline $\begin{array}{l}\text { Dummy } 4 \\
\text { (Year for dummy) }\end{array}$ & - & - & - & - & 0.4433 & $\begin{array}{l}2.7984 \\
(2010)\end{array}$ & - & - & - & \\
\hline Sample & $1999-2016$ & & 2001-2016 & & $1999-2016$ & & $2005-2016$ & & 2001-2015 & \\
\hline R-squared & 0.9844 & & 0.9121 & & 0.9599 & & 0.9738 & & 0.9774 & \\
\hline Adjusted R-squared & 0.9621 & & 0.7363 & & 0.865 & & 0.8689 & & 0.9547 & \\
\hline Durbin-Watson stat & 2.2578 & & 2.3077 & & 2.3372 & & 1.7678 & & 1.9408 & \\
\hline
\end{tabular}

Note: Each dummy year is utilised for excluding political, speculative and other factors impacted on rice markets. 
Table A B.6. Estimation of parameters for Japonica rice per capita consumption

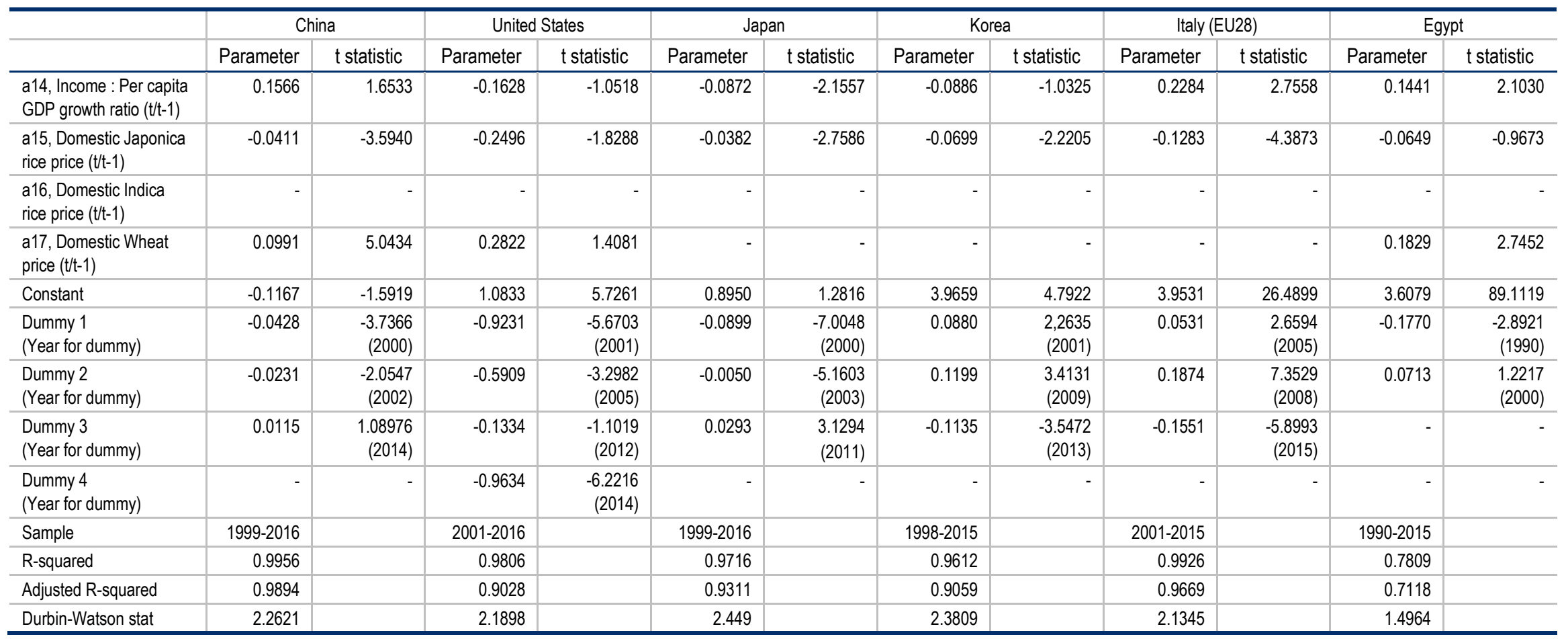

Note: Each dummy year is utilised for excluding political, speculative and other factors impacted on rice markets.

Detailed tables for baseline and scenario projections 


\section{Annex C. Detailed tables for baseline and scenario projections}

Table A C.1. Global Indica rice market (baseline projection) (1)

\begin{tabular}{|c|c|c|c|c|c|c|c|c|c|}
\hline & \multicolumn{2}{|c|}{$\begin{array}{c}\text { Harvested area } \\
(1,000 \mathrm{ha})\end{array}$} & \multirow[b]{2}{*}{$\begin{array}{l}\text { Annual growth rate } \\
(2015 / 17- \\
2040)\end{array}$} & \multicolumn{2}{|c|}{$\begin{array}{l}\text { Yield } \\
\text { (t/ha) }\end{array}$} & \multirow[b]{2}{*}{$\begin{array}{l}\text { Annual growth } \\
\text { rate } \\
(2015 / 17- \\
2040)\end{array}$} & \multicolumn{2}{|c|}{$\begin{array}{c}\text { Production } \\
(1,000 t)\end{array}$} & \multirow[b]{2}{*}{$\begin{array}{c}\text { Annual growth } \\
\text { rate } \\
(2015 / 17- \\
2040)\end{array}$} \\
\hline & $2015-17$ & 2040 & & $\begin{array}{c}2015- \\
17\end{array}$ & 2040 & & $\begin{array}{c}2015- \\
17\end{array}$ & 2040 & \\
\hline World & 147286 & 163882 & $0.5 \%$ & - & - & - & $\begin{array}{l}412 \\
129\end{array}$ & $\begin{array}{l}507 \\
538\end{array}$ & $0.9 \%$ \\
\hline Thailand & 10125 & 12457 & $0.9 \%$ & 2.8 & 2.8 & $0.1 \%$ & 18457 & $\begin{array}{r}23 \\
111\end{array}$ & $1.0 \%$ \\
\hline Viet Nam & 7726 & 8414 & $0.4 \%$ & 5.7 & 6.9 & $0.8 \%$ & 27976 & $\begin{array}{r}36 \\
471\end{array}$ & $1.2 \%$ \\
\hline Indonesia & 12197 & 14696 & $0.8 \%$ & 5.1 & 5.2 & $0.1 \%$ & 36686 & $\begin{array}{r}45 \\
080\end{array}$ & $0.9 \%$ \\
\hline Malaysia & 693 & 676 & $-0.1 \%$ & 4.2 & 4.2 & $0.0 \%$ & 1813 & 1781 & $-0.1 \%$ \\
\hline India & 43762 & 48415 & $0.4 \%$ & 3.7 & 4.2 & $0.6 \%$ & $\begin{array}{l}108 \\
035\end{array}$ & $\begin{array}{l}136 \\
995\end{array}$ & $1.0 \%$ \\
\hline China & 21007 & 19530 & $-0.3 \%$ & 6.5 & 6.9 & $0.3 \%$ & 95488 & $\begin{array}{r}94 \\
409 \\
\end{array}$ & $0.0 \%$ \\
\hline Japan & 0 & 0 & - & 0 & 0 & - & 0 & 0 & - \\
\hline Korea & 0 & 0 & - & 0 & 0 & - & 0 & 0 & - \\
\hline $\begin{array}{l}\text { United } \\
\text { States }\end{array}$ & 899 & 1204 & $1.3 \%$ & 8.0 & 8.3 & $0.2 \%$ & 5023 & 6987 & $1.4 \%$ \\
\hline EU28 & 99 & 76 & $-1.1 \%$ & 7.5 & 8.1 & $0.3 \%$ & 514 & 432 & $-0.8 \%$ \\
\hline Cambodia & 3100 & 3313 & $0.3 \%$ & 2.7 & 3.4 & $1.0 \%$ & 5195 & 6950 & $1.3 \%$ \\
\hline Lao PDR & 972 & 980 & $0.0 \%$ & 3.4 & 4.9 & $1.7 \%$ & 1958 & 2899 & $1.7 \%$ \\
\hline Myanmar & 7010 & 8195 & $0.7 \%$ & 2.9 & 3.7 & $1.1 \%$ & 12670 & $\begin{array}{r}19 \\
003\end{array}$ & $1.8 \%$ \\
\hline Philippines & 4700 & 5163 & $0.4 \%$ & 3.8 & 4.4 & $0.7 \%$ & 11665 & $\begin{array}{r}15 \\
074\end{array}$ & $1.1 \%$ \\
\hline Bangladesh & 11595 & 14631 & $1.0 \%$ & 4.4 & 5.3 & $0.8 \%$ & 33909 & $\begin{array}{r}51 \\
239\end{array}$ & $1.8 \%$ \\
\hline Brazil & 1984 & 2324 & $0.7 \%$ & 5.8 & 6.0 & $0.1 \%$ & 7889 & 9436 & $0.8 \%$ \\
\hline Côte d'Ivoire & 887 & 1001 & $0.5 \%$ & 2.4 & 2.9 & $0.8 \%$ & 1370 & 1867 & $1.4 \%$ \\
\hline Egypt & 0 & 0 & - & 0.0 & 0.0 & - & 0 & 0 & - \\
\hline Madagascar & 1450 & 1591 & $0.4 \%$ & 2.4 & 3.2 & $1.2 \%$ & 2269 & 3252 & $1.6 \%$ \\
\hline Nepal & 1451 & 1705 & $0.7 \%$ & 3.3 & 3.7 & $0.5 \%$ & 3218 & 4256 & $1.2 \%$ \\
\hline Nigeria & 3106 & 3653 & $0.7 \%$ & 2.0 & 2.3 & $0.7 \%$ & 3834 & 5335 & $1.4 \%$ \\
\hline Pakistan & 2754 & 3178 & $0.6 \%$ & 3.8 & 4.9 & $1.0 \%$ & 7050 & $\begin{array}{r}10 \\
316\end{array}$ & $1.7 \%$ \\
\hline Sri Lanka & 925 & 1175 & $1.0 \%$ & 4.1 & 4.7 & $0.5 \%$ & 2601 & 3718 & $1.6 \%$ \\
\hline
\end{tabular}


Table A C.2. Global Indica rice market (baseline projection) (2)

\begin{tabular}{|c|c|c|c|c|c|c|c|c|c|}
\hline & \multicolumn{3}{|c|}{ Consumption $(1,000 t)$} & \multicolumn{3}{|c|}{ Exports $(1,000 t)$} & \multicolumn{3}{|c|}{ Imports $(1,000 t)$} \\
\hline & $2015-17$ & 2040 & $\begin{array}{c}\text { Annual } \\
\text { growth } \\
\text { rate } \\
(2015 / 17- \\
2040)\end{array}$ & $2015-17$ & 2040 & $\begin{array}{c}\text { Annual growth } \\
\text { rate } \\
(2015 / 17- \\
2040)\end{array}$ & $\begin{array}{c}2015- \\
17\end{array}$ & 2040 & $\begin{array}{c}\text { Annual } \\
\text { growth } \\
\text { rate } \\
(2015 / 17- \\
2040)\end{array}$ \\
\hline World & 407240 & 506226 & $0.9 \%$ & 43211 & 59834 & $1.4 \%$ & 40544 & 59834 & $1.6 \%$ \\
\hline Thailand & 10754 & 10998 & $0.1 \%$ & 10661 & 12123 & $0.6 \%$ & 264 & 28 & $-9.2 \%$ \\
\hline Viet Nam & 22200 & 26497 & $0.8 \%$ & 6192 & 10421 & $2.3 \%$ & 400 & 469 & $0.7 \%$ \\
\hline Indonesia & 37883 & 47096 & $1.0 \%$ & 2 & 2 & $0.0 \%$ & 1133 & 2038 & $2.6 \%$ \\
\hline Malaysia & 2731 & 3206 & $0.7 \%$ & 32 & 0 & - & 872 & 1430 & $2.2 \%$ \\
\hline India & 95565 & 118087 & $0.9 \%$ & 11604 & 18957 & $2.2 \%$ & 0 & 0 & - \\
\hline China & 95239 & 99766 & $0.2 \%$ & 356 & 352 & $0.0 \%$ & 5199 & 7175 & $1.4 \%$ \\
\hline Japan & 263 & 236 & $-0.5 \%$ & 0 & 200 & - & 263 & 236 & $-0.5 \%$ \\
\hline Korea & 52 & 57 & $0.4 \%$ & 0 & 0 & - & 52 & 57 & $0.4 \%$ \\
\hline United States & 3344 & 3848 & $0.6 \%$ & 2555 & 3925 & $1.9 \%$ & 772 & 778 & $0.0 \%$ \\
\hline E U28 & 2222 & 1912 & $-0.7 \%$ & 37 & 44 & $0.8 \%$ & 1684 & 1521 & $-0.4 \%$ \\
\hline Cambodia & 4000 & 5256 & $1.2 \%$ & 1150 & 1727 & $1.8 \%$ & 23 & 25 & $0.4 \%$ \\
\hline Lao PDR & 2077 & 3990 & $2.9 \%$ & 67 & 0 & $-100.0 \%$ & 137 & 1094 & $9.5 \%$ \\
\hline Myanmar & 10100 & 14240 & $1.5 \%$ & 2650 & 4770 & $2.6 \%$ & 18 & 18 & - \\
\hline Philippines & 12967 & 17396 & $1.3 \%$ & 0 & 0 & - & 1300 & 2340 & $2.6 \%$ \\
\hline Bangladesh & 35100 & 52601 & $1.8 \%$ & 4 & 10 & $4.1 \%$ & 1164 & 1388 & $0.8 \%$ \\
\hline Brazil & 7975 & 12051 & $1.8 \%$ & 742 & 751 & $0.1 \%$ & 739 & 3372 & $6.8 \%$ \\
\hline Côte d'Ivoire & 2767 & 4309 & $1.9 \%$ & 27 & 0 & $-100.0 \%$ & 1350 & 2435 & $2.6 \%$ \\
\hline Egypt & 84 & 120 & $1.6 \%$ & 0 & 0 & - & 84 & 120 & $1.6 \%$ \\
\hline Madagascar & 2664 & 4033 & $1.8 \%$ & 0 & 0 & - & 395 & 781 & $3.0 \%$ \\
\hline Nepal & 3758 & 5948 & $2.0 \%$ & 0 & 0 & - & 540 & 1692 & $5.1 \%$ \\
\hline Nigeria & 6550 & 12265 & $2.8 \%$ & 0 & 0 & - & 2400 & 6937 & $4.7 \%$ \\
\hline Pakistan & 3033 & 6902 & $3.6 \%$ & 4005 & 3441 & $-0.7 \%$ & 7 & 27 & $6.0 \%$ \\
\hline Sri Lanka & 3108 & 3978 & $1.1 \%$ & 3 & 0 & - & 394 & 254 & $-1.9 \%$ \\
\hline
\end{tabular}

Table A C.3. Global Japonica rice market (baseline projection) (1)

\begin{tabular}{|c|c|c|c|c|c|c|c|c|c|}
\hline & \multicolumn{2}{|c|}{ Harvested area } & \multirow{2}{*}{$\begin{array}{c}\text { (1,000 ha) } \\
\text { Annual } \\
\text { growth rate } \\
(2015 / 17- \\
2040)\end{array}$} & \multicolumn{2}{|l|}{ Yield } & & \multicolumn{2}{|c|}{ Production } & \multirow{2}{*}{$\begin{array}{c}(1,000 \mathrm{t}) \\
\text { Annual } \\
\text { growth rate } \\
(2015 / 17- \\
2040)\end{array}$} \\
\hline & $2015-17$ & 2040 & & $2015-17$ & 2040 & $\begin{array}{c}\text { Annual } \\
\text { growth rate } \\
(2015 / 17- \\
2040)\end{array}$ & $2015-17$ & 2040 & \\
\hline World & 13160 & 13337 & $0.1 \%$ & - & - & - & 70721 & $\begin{array}{r}73 \\
641\end{array}$ & $0.2 \%$ \\
\hline China & 9181 & 9233 & $0.0 \%$ & 7.8 & 7.8 & $0.0 \%$ & 50083 & $\begin{array}{r}50 \\
287\end{array}$ & $0.0 \%$ \\
\hline Japan & 1571 & 1430 & $-0.4 \%$ & 6.7 & 7.4 & $0.4 \%$ & 7679 & 7715 & $0.0 \%$ \\
\hline Korea & 778 & 756 & $-0.1 \%$ & 7.1 & 7.4 & $0.2 \%$ & 4165 & 4229 & $0.1 \%$ \\
\hline United States & 188 & 214 & $0.6 \%$ & 9.7 & 10.4 & $0.3 \%$ & 1280 & 1565 & $0.9 \%$ \\
\hline EU28 & 337 & 277 & $-0.8 \%$ & 6.6 & 6.7 & $0.1 \%$ & 1541 & 1296 & $-0.7 \%$ \\
\hline Egypt & 754 & 989 & $1.2 \%$ & 8.4 & 8.8 & $0.2 \%$ & 4367 & 6011 & $1.4 \%$ \\
\hline
\end{tabular}


Table A C.4. Global Japonica rice market (the baseline projection) (2)

\begin{tabular}{|c|c|c|c|c|c|c|c|c|c|}
\hline & \multicolumn{2}{|c|}{ Consumption } & \multirow{2}{*}{$\begin{array}{c}(1000 t) \\
\text { Annual } \\
\text { growth rate } \\
(2015 / 17- \\
2040)\end{array}$} & \multicolumn{2}{|c|}{ Exports } & \multirow{2}{*}{$\begin{array}{c}(1000 \mathrm{t}) \\
\text { Annual } \\
\text { growth rate } \\
(2015 / 17- \\
2040)\end{array}$} & \multicolumn{2}{|c|}{ Imports } & \multirow{2}{*}{$\begin{array}{c}(1000 t) \\
\text { Annual } \\
\text { growth rate } \\
(2015 / 17- \\
2040)\end{array}$} \\
\hline & $2015-17$ & 2040 & & $2015-17$ & 2040 & & $2015-17$ & 2040 & \\
\hline World & 67650 & 73572 & $0.4 \%$ & 2067 & 2977 & $1.6 \%$ & 2064 & 2975 & $1.6 \%$ \\
\hline China & 46410 & 49518 & $0.3 \%$ & 436 & 734 & $2.3 \%$ & 1 & 1 & $0.0 \%$ \\
\hline Japan & 8254 & 8412 & $0.1 \%$ & 50 & 21 & $-3.8 \%$ & 439 & 694 & $2.0 \%$ \\
\hline Korea & 4527 & 4532 & $0.0 \%$ & 23 & 27 & $0.7 \%$ & 325 & 353 & $0.4 \%$ \\
\hline United States & 624 & 615 & $-0.1 \%$ & 744 & 952 & $1.1 \%$ & 18 & 20 & $0.5 \%$ \\
\hline EU28 & 1378 & 1325 & $-0.2 \%$ & 260 & 161 & $-2.1 \%$ & 164 & 204 & $1.0 \%$ \\
\hline Egypt & 4116 & 5370 & $1.2 \%$ & 117 & 641 & $7.7 \%$ & 0 & 0 & - \\
\hline
\end{tabular}

Table A C.5. Scenario impact on world Indica and Japonica rice markets (2015/17-2040) (1)

\begin{tabular}{|c|c|c|c|c|c|}
\hline & & $\begin{array}{c}\text { Impact between } \\
\text { Scenario } 1 \text { and baseline } \\
\text { from } 2015 / 17 \text { to } 2040\end{array}$ & $\begin{array}{c}\text { Impact between } \\
\text { Scenario } 2 \text { and baseline } \\
\text { from } 2015 / 17 \text { to } 2040\end{array}$ & $\begin{array}{c}\text { Impact between } \\
\text { Scenario } 3 \text { and baseline } \\
\text { from } 2015 / 17 \text { to } 2040 \\
\end{array}$ & $\begin{array}{c}\text { Impact between } \\
\text { Scenario } 4 \text { and baseline } \\
\text { from } 2015 / 17 \text { to } 2040 \\
\end{array}$ \\
\hline \multicolumn{6}{|c|}{ Indica rice market } \\
\hline \multicolumn{2}{|c|}{ Country } & Viet Nam & Viet Nam & The Philippines & The Philippines \\
\hline & \begin{tabular}{l|l} 
Yield \\
\end{tabular} & $-9.1 \%$ & $-1.5 \%$ & $0.0 \%$ & $-1.4 \%$ \\
\hline & Area harvested & $0.1 \%$ & $-1.7 \%$ & $-0.9 \%$ & $-2.5 \%$ \\
\hline & Production & $-9.0 \%$ & $-3.2 \%$ & $-0.9 \%$ & $-3.9 \%$ \\
\hline & Consumption & $-0.1 \%$ & $-0.03 \%$ & $-0.03 \%$ & $-0.1 \%$ \\
\hline & Exports & $-34.0 \%$ & $-12.1 \%$ & - & - \\
\hline & Imports & $-3.4 \%$ & $-1.2 \%$ & $6.0 \%$ & $27.2 \%$ \\
\hline \multicolumn{6}{|c|}{ World } \\
\hline & Production & $-0.3 \%$ & $-0.1 \%$ & $-0.01 \%$ & $-0.1 \%$ \\
\hline & Consumption & $-0.3 \%$ & $-0.1 \%$ & $-0.01 \%$ & $-0.1 \%$ \\
\hline & Exports & $-3.8 \%$ & $-1.4 \%$ & $0.1 \%$ & $0.3 \%$ \\
\hline & Imports & $-3.8 \%$ & $-1.4 \%$ & $0.1 \%$ & $0.3 \%$ \\
\hline & $\begin{array}{l}\text { International Indica } \\
\text { rice price }\end{array}$ & $7.0 \%$ & $2.4 \%$ & $0.3 \%$ & $1.2 \%$ \\
\hline \multicolumn{6}{|c|}{ Japonica rice market } \\
\hline \multicolumn{6}{|c|}{ World } \\
\hline & \begin{tabular}{|l|} 
Production \\
\end{tabular} & $0.02 \%$ & $0.01 \%$ & $0.001 \%$ & $0.004 \%$ \\
\hline & Consumption & $0.02 \%$ & $0.01 \%$ & $0.001 \%$ & $0.004 \%$ \\
\hline & Exports & $-0.1 \%$ & $-0.04 \%$ & $-0.004 \%$ & $-0.02 \%$ \\
\hline & Imports & $-0.1 \%$ & $-0.04 \%$ & $-0.004 \%$ & $-0.02 \%$ \\
\hline & $\begin{array}{l}\text { International } \\
\text { Japonica rice price }\end{array}$ & $0.4 \%$ & $0.1 \%$ & $0.02 \%$ & $0.07 \%$ \\
\hline
\end{tabular}


Table A C.6. Scenario impact on world Indica and Japonica rice markets (2015/17-2040) (2)

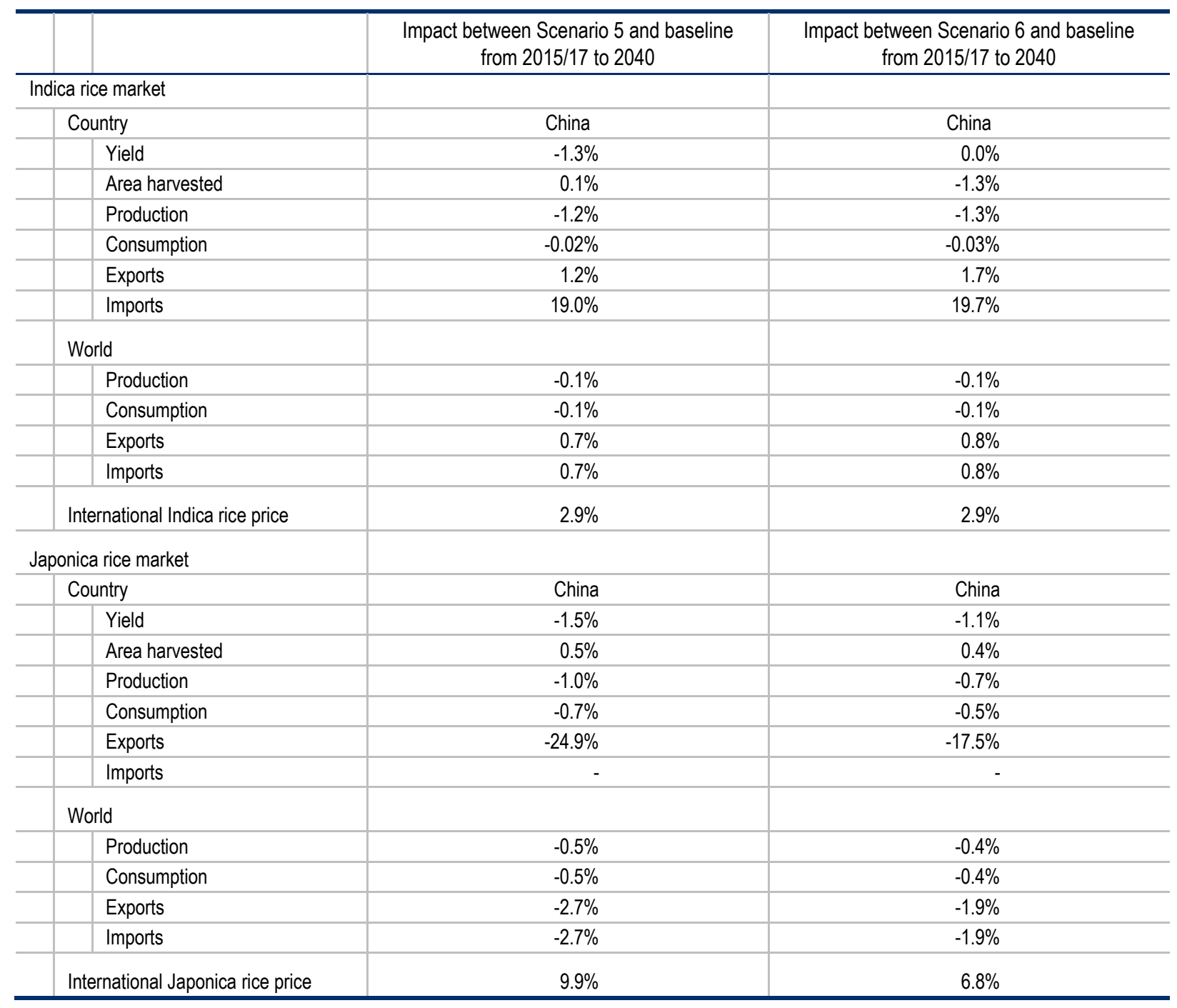

Table A C.7. Scenario impact on international Indica and Japonica rice prices (2015/17-2040)

\begin{tabular}{l|l|l|c|c|c|c|c|c}
\hline & & \multicolumn{3}{|c|}{ Indica rice price } & \multicolumn{3}{c}{ Japonica rice price } \\
\hline & Country & \multicolumn{1}{|c|}{$\begin{array}{c}\text { Agricultural } \\
\text { investments }\end{array}$} & $\begin{array}{c}\text { Coefficient of } \\
\text { variation } \\
\text { (CV) }\end{array}$ & $\begin{array}{c}\text { Standard } \\
\text { deviation }\end{array}$ & Average & $\begin{array}{c}\text { Coefficient } \\
\text { of variation } \\
\text { (CV) }\end{array}$ & $\begin{array}{c}\text { Standard } \\
\text { deviation }\end{array}$ & Average \\
\hline Baseline & & 0.1083 & 47.8742 & 442.2263 & 0.1776 & 5.9538 & 33.5173 \\
\hline Scenario 1 & Viet Nam & $\begin{array}{l}\text { Agricultural } \\
\text { knowledge }\end{array}$ & 0.1339 & 63.3054 & 472.7640 & 0.1794 & 6.0375 & 33.6542 \\
\hline Scenario 2 & Viet Nam & Infrastructure & 0.1164 & 52.6988 & 452.8127 & 0.1783 & 5.9839 & 33.5661 \\
\hline Scenario 3 & Philippines & $\begin{array}{l}\text { Agricultural } \\
\text { knowledge }\end{array}$ & 0.1091 & 48.3614 & 443.3616 & 0.1777 & 5.9571 & 33.5226 \\
\hline Scenario 4 & Philippines & Infrastructure & 0.1121 & 50.1778 & 447.4401 & 0.1780 & 5.9688 & 33.5415 \\
\hline Scenario 5 & China & $\begin{array}{l}\text { Agricultural } \\
\text { knowledge }\end{array}$ & 0.1174 & 53.3731 & 454.7018 & 0.2215 & 8.1855 & 36.9630 \\
\hline Scenario 6 & China & Infrastructure & 0.1175 & 53.4634 & 454.9910 & 0.2079 & 7.4631 & 35.8951 \\
\hline
\end{tabular}




\section{OECD FOOD, AGRICULTURE AND FISHERIES PAPERS}

The report was declassified by the OECD Working Party on Agricultural Policies and Markets in March 2021 and was prepared for publication by the OECD Secretariat.

This report, as well as any data and any map included herein, are without prejudice to the status of or sovereignty over any territory, to the delimitation of international frontiers and boundaries and to the name of any territory, city or area.

The statistical data for Israel are supplied by and under the responsibility of the relevant Israeli authorities. The use of such data by the OECD is without prejudice to the status of the Golan Heights, East Jerusalem and Israeli settlements in the West Bank under the terms of international law.

Comments are welcome and can be sent to tad.contact@oecd.org. 